\title{
Performance of a Multisensor Smart Ring to Evaluate Sleep: In-Lab and Home-Based Evaluation Relative to Polysomnography and Actigraphy: Importance of Generalized Versus Personalized Scoring
}

Michael A. Grandner PhD MTR ${ }^{1}$, Zohar Bromberg $\mathrm{MS}^{2}$, Zoe Morrell $\mathrm{MPH}^{2}$, Arnulf Graf $\mathrm{PhD}^{2}$, Stephen Hutchison $^{1}$, and Dustin Freckleton $\mathrm{MD}^{2}$

${ }^{1}$ Sleep and Health Research Program, Department of Psychiatry, University of Arizona College of Medicine

${ }^{2}$ Happy Health, Inc.

Corresponding Author: Zoe Morrell, Happy Health, Inc. 3200 Gracie Kiltz Lane Austin, Texas 78758.

Short running title: Performance of a Multisensor Smart Ring to Evaluate Sleep

Conflict of Interest Statement: Zohar Bromberg, Zoe Morrell, Arnulf Graf and Dustin Freckletons are employees of Happy Health, Inc. Michael Grander reports grants from Jazz Pharmaceuticals and CeraZ, and has received consulting fees in the past 24 months from Fitbit, Natrol, Casper, Athleta, Smartypants Vitamins, Idorsia, Jazz Pharmaceuticals, New York University, and University of Maryland. Stephen Hutchinson reports no potential conflicts.

Data Accessibility statement: Data from this study are not available due to the raw data being important intellectual property for Happy Health, Inc. 
medRxiv preprint doi: https://doi.org/10.1101/2021.12.22.21268267; this version posted January 1, 2022. The copyright holder for this preprint (which was not certified by peer review) is the author/funder, who has granted medRxiv a license to display the preprint in perpetuity.

All rights reserved. No reuse allowed without permission.

\section{STATEMENT OF SIGNIFICANCE}

Multisensor sleep wearable devices have proliferated the commercial market in recent years. In this study, we evaluated the sleep-tracking performance of the novel Happy Ring, alongside the Actiwatch, Fitbit, Whoop, and Oura Ring devices, relative to both in-lab and at-home polysomnography, following state-of-the-science guidelines. The Happy Ring includes additional sensors infrequently used in the assessment of sleep, including skin temperature and electrodermal activity. Also, the study evaluates a standard "generalized" scoring algorithm to a new "personalized" approach, using a machine-learning strategy that tailors the scoring algorithm to the individual. Both the Happy Ring "generalized" and "personalized" scoring algorithms demonstrated good sensitivity and specificity for the detection of sleep both in the laboratory and at home, with the personalized approach performing statistically significantly better in accuracy than the other evaluated devices. Perhaps more importantly, the Happy Personalized algorithm also demonstrated significantly higher specificity than other devices, an area that sleep trackers often struggle with. The current findings demonstrate that the Happy Ring compares well to inlab PSG and its "personalized" approach offers a potential innovation in sleep detection accuracy. 
medRxiv preprint doi: https://doi.org/10.1101/2021.12.22.21268267; this version posted January 1, 2022. The copyright holder for this preprint (which was not certified by peer review) is the author/funder, who has granted medRxiv a license to display the preprint in perpetuity.

All rights reserved. No reuse allowed without permission.

\begin{abstract}
Study Objectives: Wearable sleep technology has rapidly expanded across the consumer market due to advances in technology and increased interest in personalized sleep assessment to improve health and performance. In this study, we tested the performance of a novel device, alongside other commercial wearables, against in-lab and at-home polysomnography (PSG).
\end{abstract}

Methods: 36 healthy adults were assessed across 77 nights while wearing the Happy Ring, as well as the Actiwatch, Fitbit, Whoop, and Oura Ring devices. Subjects participated in a single night of in-lab PSG and 2 nights of at-home PSG. The Happy Ring includes sensors for skin conductance, movement, heart rate, and skin temperature. Epoch-by-epoch analyses compared the wearable devices to both in-lab and at-home PSG. The Happy Ring utilized two machine-learning derived scoring algorithms: a "generalized" algorithm that applied broadly to all users, and a "personalized" algorithm that adapted to individual subjects' data.

Results: Compared to in-lab PSG, the "generalized" and "personalized" algorithms demonstrated good sensitivity (94\% and 93\%, respectively) and specificity (70\% and 83\%, respectively). The other wearable devices also demonstrated good sensitivity (89\%-94\%) but lower specificity (19\%-54\%), relative to the Happy Ring. Accuracy was $91 \%$ for "generalized" and $92 \%$ for "personalized" algorithms, compared to other devices that ranged from 84\%-88\%. The generalized algorithm demonstrated an accuracy of $67 \%, 85 \%$, and $85 \%$ for light, deep, and REM sleep, respectively. The personalized algorithm was $81 \%, 95 \%$, and $92 \%$ accurate for light, deep, and REM sleep, respectively. 
medRxiv preprint doi: https://doi.org/10.1101/2021.12.22.21268267; this version posted January 1, 2022. The copyright holder for this preprint (which was not certified by peer review) is the author/funder, who has granted medRxiv a license to display the preprint in perpetuity. All rights reserved. No reuse allowed without permission.

Conclusions: The Happy Ring performed well at home and in the lab, especially regarding sleepwake detection. The personalized algorithm demonstrated improved detection accuracy over the generalized approach and other devices, suggesting that adaptable, dynamic algorithms can enhance sleep detection accuracy. 
medRxiv preprint doi: https://doi.org/10.1101/2021.12.22.21268267; this version posted January 1, 2022. The copyright holder for this preprint (which was not certified by peer review) is the author/funder, who has granted medRxiv a license to display the preprint in perpetuity.

All rights reserved. No reuse allowed without permission.

\section{INTRODUCTION}

Real-world sleep health is increasingly recognized as an important factor in physical and mental health ${ }^{1-6}$. Wearable technology provides opportunities to assess sleep health in real-world situations so that associations with relevant health and performance outcomes can be examined in the context of reliable, objective recordings in naturalistic settings ${ }^{7-11}$. This has proven useful, as wearable technology to assess sleep has been used to explore associations with cardiovascular disease ${ }^{12,13}$, metabolic dysregulation ${ }^{12,14}$, inflammation $^{15,16}$, mental health ${ }^{17,18}$, physical performance ${ }^{19}$, and other outcomes, including mortality ${ }^{20}$.

As the technology develops, there is an increasing proliferation of wearable devices aimed at the consumer market $^{21,22}$. Initially, these devices offered a high degree of scalability, but presented significant limitations on accuracy ${ }^{23-25}$. However, this gap has been closing recently, as studies increasingly demonstrate that newer consumer sleep-tracking devices can reliably estimate sleep-wake states with at least as much accuracy as standard scientific devices ${ }^{26-29}$. Improved sleep-wake prediction performance in consumer devices is likely related to the increased capabilities of physiologic signals in wearable technology ${ }^{27,30}$. Additionally, scoring algorithms have advanced, now frequently including complex machine learning algorithms that may also improve sleep-wake detection ${ }^{31-33}$.

For these reasons, standards for the validation ${ }^{9,34}$ and implementation ${ }^{10,35}$ of new technologies have been put forward. Further, the concept of evaluating the performance of devices relative to their context has emerged as a strategy for addressing the limitations of more traditional validation approaches ${ }^{10,36}$. With the establishment of these standards, applications of novel sensors and scoring strategies have been called for ${ }^{11}$.

Accordingly, the present study evaluates the performance of a novel device both in the laboratory and at home, relative to a gold-standard comparator (in-lab polysomnography; PSG), an at-home PSG device (Dreem Headband), and several other commercially available wearable devices. Specifically, this study aims to (1) quantify the accuracy of sleep-wake detection relative to in-lab and at-home sleep assessment by evaluating sensitivity and specificity, (2) quantify the accuracy of sleep stage classification compared to 
medRxiv preprint doi: https://doi.org/10.1101/2021.12.22.21268267; this version posted January 1, 2022. The copyright holder for this preprint (which was not certified by peer review) is the author/funder, who has granted medRxiv a license to display the preprint in perpetuity.

All rights reserved. No reuse allowed without permission.

in-lab and at-home sleep assessment by evaluating sensitivity and specificity, (3) quantify the relative performance of the investigational device compared to existing devices that have previously demonstrated good performance, and (4) evaluate the relative performance of two difference machine learning approaches for sleep scoring.

\section{METHODS}

\section{Participants}

Participants were recruited through multiple strategies, including emailing past research study participants, and using word of mouth. Participants were eligible to participate if they: fell within the age range of 20 to 65 years of age, had no known or diagnosed sleep, mental health or significant medical disorders, were not pregnant, had no regular nicotine use within the past month, no habitual use of antidepressants, beta-blockers, stimulant medications, prescription pain medications, or anti-seizure medications within the past three months, had not used THC products within the past two weeks, and had a habitual sleep window and average nightly sleep within a normal range. A normal sleep window was defined as average bedtime after 9 pm and before 2 am and average wake-up time after 5 am and before $10 \mathrm{am}$. The study protocol was approved by Solutions Institutional Review Board.

\section{Measures}

The study device ("Happy Ring") consisted of a finger-worn device that includes sensors for: (1) electrodermal activity (EDA), (2) 3-axis accelerometry, (3) photoplethysmography (PPG) derived heart rate, and (4) skin temperature. EDA was measured using a medical grade 3-electrode impedance sensor, with data collected at $8 \mathrm{~Hz}$. Accelerometry was measured using a smartphone-class microelectromechanical, multiaxial accelerometer embedded within the device, with data collected at $104 \mathrm{~Hz}$. Data collected at $100 \mathrm{~Hz}$ from the PPG sensor provided the opportunity to assess heart rate, computed using a proprietary algorithm. Skin temperature was assessed using a medical grade $+/-0.1^{\circ} \mathrm{C}$ accuracy temperature sensor, data 
medRxiv preprint doi: https://doi.org/10.1101/2021.12.22.21268267; this version posted January 1, 2022. The copyright holder for this preprint (which was not certified by peer review) is the author/funder, who has granted medRxiv a license to display the preprint in perpetuity.

All rights reserved. No reuse allowed without permission.

were collected at $1 \mathrm{~Hz}$. Lastly, the internal clock of the unit computed time elapsed since the start and end of each sleep period. From these signals, data were merged into 30-sec epochs across all channels. Key metrics obtained from the device included epoch-by-epoch sleep and wake estimations, as well as time in bed (TIB), sleep latency (SL), wake after sleep onset (WASO), and total sleep time (TST; computed as TIB - SL - WASO). In addition, a proprietary algorithm, was used to detect sleep stages, further classifying sleep as either "Deep" (Non-rapid eye movement (NREM); stage N3), "Light" (NREM stage N1 or N2), or REM. Sleep stages were determined based on a machine learning algorithm.

In-lab polysomnography (PSG) was accomplished using a Respironics Alice 6 diagnostic sleep system, with Natus Neurology Gold Cups as leads. The system used electroencephalogram (EEG; F3-A2,F4A1,C3-A2,C4-A1,O1-A2,O2-A1), electromyogram amplifier module (EMG; chin) and electrooculogram (EOG; LOC-A2, ROC-A2) channels. In addition to 3 electrocardiogram (EKG) patches, chest and abdomen belts, and a thermistor and a nasal canula. Scoring was performed by a certified polysomnographic technician, following the standard American Academy of Sleep Medicine scoring rules ${ }^{37}$.

At-home sleep assessment was performed using the Dreem2 headband device (Dreem) to record electroencephalographic and other signals. Participants wore the Dreem2 headband on two consecutive nights at home. Data were scored using the standard Dreem settings. The Dreem headband has demonstrated good performance for assessment of sleep in the home ${ }^{38}$. Although the Dreem headband does not completely replace standard in-laboratory PSG, it does approximate laboratory PSG better than sleep wearables that use only peripheral signals ${ }^{28,39}$.

In addition to the Happy Ring, participants were also asked to wear up to four other sleep-tracking devices. First, participants were asked to wear the Actiwatch 2 from Philips Respironics. The Actiwatch is a goldstandard actigraphy device, with well-characterized validation data ${ }^{7}$ The Actiwatch uses a 3-axis accelerometer and scores sleep based on movement data. Data were scored using the standard algorithm, without additional hand-scoring. Second, participants were asked to wear a Fitbit device (Fitbit Charge 2, Fitbit Inc.). This commercially available device uses both accelerometry and PPG heart rate data to estimate sleep 
medRxiv preprint doi: https://doi.org/10.1101/2021.12.22.21268267; this version posted January 1, 2022. The copyright holder for this preprint (which was not certified by peer review) is the author/funder, who has granted medRxiv a license to display the preprint in perpetuity.

All rights reserved. No reuse allowed without permission.

and wake ${ }^{30}$. Previous studies have shown that the Fitbit device is a valid and reliable tool for assessment of sleep, with strong agreement compared with $\mathrm{PSG}^{28,30,40,41}$. Third, participants were asked to wear a Whoop device (Whoop 3.0, Whoop Inc.). This device is also commercially available and uses both movement and PPG data to estimate sleep ${ }^{42,43}$. Some previous studies have demonstrated that this device is accurate when compared to $\mathrm{PSG}^{42}$. Finally, participants were asked to wear an Oura Ring (model V2). Like the Happy Ring, the Oura Ring is worn on the finger, and includes sensors for accelerometry and PPG heart rate data for the estimation of sleep ${ }^{44}$. Due to inventory constraints and a desire to maintain participant compliance to the study protocol, not all participants wore all devices during the three nights of data collection. Devices were rotated the between users to make sure the same number of nights of data were available for all devices.

\section{Procedure}

All participants participated in a three-night study which included one night in a sleep laboratory and two subsequent nights at home. In the lab, the sleep period was defined as lights off and lights on according to the PSG labels for the lab trials. At home, the sleep period was defined as the start and end of the Dreem headband recording.

Preprocessing of signals include interpolation of missing data when the gap was less than 3 seconds. When the gap was larger, null /missing values were used. Signals were interpolated to $52 \mathrm{~Hz}, 8 \mathrm{~Hz}, 1 \mathrm{~Hz}$, and 1 $\mathrm{Hz}$ for acceleration, EDA, heart rate, and temperature, respectively. The sleep lab and at-home sleep datasets were analyzed separately.

All data from the Happy Ring were analyzed in 30-second epochs. From these data, 211 features were extracted: 55 features from acceleration, 26 features from EDA, 103 features from heart rate, 26 features from temperature, and 1 feature from time elapsed. Examples of features are mean, standard deviation, range, and frequency of values and variables. To standardize values, they were converted to z-scores them for each data sample, defined as a night of sleep. 
medRxiv preprint doi: https://doi.org/10.1101/2021.12.22.21268267; this version posted January 1, 2022. The copyright holder for this preprint (which was not certified by peer review) is the author/funder, who has granted medRxiv a license to display the preprint in perpetuity.

All rights reserved. No reuse allowed without permission.

\section{Determining Sleep-Wake and Sleep Stage Data with the Happy Ring}

A central part of the analysis was how the train-test split was defined. In other words, determining what time snippets of the data were used to learn the parameters of the classifier, and what snippets were used to infer sleep stages ${ }^{45,46}$.Two sets of metrics were used to quantify sleep stage prediction accuracy:

1. "Happy Generalized" was developed by doing a leave-one-out cross-validation ${ }^{45,46}$ at the level of the nights. This approach involved training on all but one night and testing on this night; repeated across nights. This approach tests the generalization ability of the sleep stage classifier across subject nights, with learning and inference done on different subject nights.

2. "Happy Personalized" was developed by training and testing on all subjects for different non-overlapping time windows, allowing for learning and inference on identical groups of subjects. This included a crossvalidation where $80 \%$ of the data were used for training, and $20 \%$ of the data were reserved for testing.

For testing, the segments for each night were stitched back together. This approach evaluates the personalization of the sleep stage classification.

If the data contained many subjects that had a wide range of physiological responses, both approaches would yield similar results. However, if the data were based on a small subset of subjects or nights, both approaches can give different results reflecting the data sampling bias, and not the inference quality ${ }^{45,46}$. Therefore, the Happy Generalized approach could underestimate the sleep stage prediction accuracy because training and testing data may be very different, whereas the Happy Personalized scoring method would give a more accurate representation of the prediction accuracy because the classifier learns from each subject night.

Both approaches inform on different aspects of sleep stage prediction. Happy Generalized can be interpreted as a generalized approach that does not take into consideration the evaluated subject. On the other hand, Happy Personalized used the evaluated subject for learning, providing a more individualized experience. 
medRxiv preprint doi: https://doi.org/10.1101/2021.12.22.21268267; this version posted January 1, 2022. The copyright holder for this preprint (which was not certified by peer review) is the author/funder, who has granted medRxiv a license to display the preprint in perpetuity.

All rights reserved. No reuse allowed without permission.

In the context of our research, Happy Generalized validated the models by setting a baseline, and Happy Personalized improved upon the baseline by personalizing the sleep stage prediction process.

The training data exhibited a strong class imbalance (22\% deep, $41 \%$ light, $27 \%$ REM and 10\% awake samples across all nights). To overcome this, the training data were randomly under-sampled. A random forest classifier was trained and determined the optimal number of estimators as 10 using a cross-validated grid search. The classifier provided a probability-of-class membership for each sample in the unbalanced testing set. Then, post-processing of interpolation and Gaussian smoothing was applied to this probability distribution before making a categorical prediction by finding the location of the maximum of this probability distribution. Finally, ad hoc heuristics were used to avoid unlikely changes in sleep stages, for example, from awake to deep sleep. Those heuristics included removing short deep sleep stages if they occurred right after an awake period, removing short awake periods if they occurred right after deep periods, and removing all short periods in any of the sleep stages, regardless of the previous sleep stage.

\section{Data Analyses}

First, to determine whether sleep continuity and sleep architecture significantly differed between the Happy Ring and both laboratory polysomnography and Dreem recordings at time, linear models evaluated mean differences between the values obtained by the Happy Ring and either laboratory PSG or Dreem results, separately. Sleep continuity was evaluated by determining total sleep time and wake after sleep onset. Sleep architecture was defined as time in each of the following sleep stages: deep, light, REM and wake.

Second, classification accuracy was assessed using a confusion matrix, separately evaluating the Happy Generalized and Happy Personalized against both laboratory PSG and Dreem.

Third, accuracy of both the Happy Generalized and Happy Personalized algorithms for asleep versus awake, as well as for individual sleep stages relative to laboratory PSG and Dreem was compared to similar values 
medRxiv preprint doi: https://doi.org/10.1101/2021.12.22.21268267; this version posted January 1, 2022. The copyright holder for this preprint (which was not certified by peer review) is the author/funder, who has granted medRxiv a license to display the preprint in perpetuity.

All rights reserved. No reuse allowed without permission.

obtained from Fitbit, Whoop, and Oura devices, and sleep-wake sensitivity and specificity were compared across Happy Generalized, Happy Personalized, Fitbit, Whoop, Oura, and Actiwatch, relative to laboratory PSG and Dreem.

Fourth, mean differences between PSG or Dreem and wearables (Happy Generalized, Happy Personalized, Fitbit, Whoop, Oura, and Actiwatch) were compared for TST and WASO, and sleep stages for all devices except Actiwatch, which does not provide sleep staging results.

\section{RESULTS}

Data were collected from 40 participants, who met inclusion criteria, over the course of 122 nights. After removing data where device failure or data quality issues occurred, data were ultimately analyzed for 36 adults across 77 nights of sleep. The mean age of the sample was 33.8 years $(\mathrm{SD}=7.8$ years, range $=22$ years - 51 years). The sample was $56 \%$ female, mean body mass index was 23.4 ( $\mathrm{SD}=3.8)$. The sample was $30.6 \%$ non-Hispanic White. A breakdown of sample characteristics is reported in Table 1.

When polysomnographic values from the laboratory and home gold standards were compared, small, nominal differences were seen. Figure 1 depicts observed values for TST, WASO, and sleep stages across both settings. On average, no significant difference was observed between TST and WASO; mean TST was 432 minutes ( $\mathrm{SD}=38$ minutes) in the lab and 442 minutes ( $\mathrm{SD}=50$ minutes) at home. Mean WASO was 24 minutes ( $\mathrm{SD}=16$ minutes) in the lab and 24 minutes ( $\mathrm{SD}=14$ minutes) at home. The sleep stage distribution was different between lab and home data recordings, with a greater relative percentage of the night in light sleep in the laboratory and greater relative percentages of deep and REM sleep at home.

Figure 2 depicts examples of Happy Ring data superimposed over both laboratory and home polysomnography. Figures 2A and 2B depict examples where the Happy Ring performed well, in-lab and at-home, respectively. Figures 2C and 2D depict examples where the Happy Ring performed typically in-lab and at- 
medRxiv preprint doi: https://doi.org/10.1101/2021.12.22.21268267; this version posted January 1, 2022. The copyright holder for this preprint (which was not certified by peer review) is the author/funder, who has granted medRxiv a license to display the preprint in perpetuity. All rights reserved. No reuse allowed without permission.

home, respectively, and Figures 2E and 2F depicts an example where the Happy Ring performed poorly inlab and at-home, respectively.

Sleep-wake detection and sleep staging performance in a laboratory setting

Table 2 presents the performance of sleep-wake detection in a laboratory setting for the Happy Personalized and Happy Generalized algorithms, along with that of the other studied devices: Oura, Whoop, Fitbit, and Actiwatch. The overall sleep-wake detection accuracy for the Happy devices was $0.92(\mathrm{SD}=0.04)$ using the Happy Personalized algorithm, and 0.91 (SD = 0.04) using the Happy Generalized algorithm. Sleepwake detection accuracy values for other devices were $0.88(\mathrm{SD}=0.05)$ for Oura, $0.86(\mathrm{SD}=0.05)$ for Whoop, $0.84(\mathrm{SD}=0.07)$ for Fitbit, and $0.85(\mathrm{SD}=0.07)$ for Actiwatch. Table 2 also reports sensitivity, specificity, positive predictive value (PPV) and negative predictive value (NPV) for these devices. In the laboratory environment, the Happy Personalized algorithm demonstrated significantly higher values for accuracy and specificity for sleep-wake detection compared to all other devices studied $(P<.001)$.

The performance of sleep stage predictions for light, deep, REM and wake were also evaluated. Table 3 reports values for accuracy, sensitivity, specificity, PPV and NPV for all study devices compared to the lab PSG. For light, deep, and REM sleep, Happy Personalized demonstrated the highest values for sensitivity, specificity, and accuracy compared to other devices studied.

For data collected in the sleep lab, total sleep time estimates, relative to PSG values, are depicted in Figure 3A, and differences in WASO across devices are reported in Figure 3B. Figure 3C shows differences for sleep stages across devices.

Bland-Altman plots comparing the Happy Generalized and Happy Personalized algorithms were computed. Data comparing these algorithms relative to sleep continuity and sleep stages are reported in supplementary figures S1 and S2, presenting Happy Generalized and Happy Personalized, respectively.

Sleep-wake detection and sleep-staging performance in a home setting 
medRxiv preprint doi: https://doi.org/10.1101/2021.12.22.21268267; this version posted January 1, 2022. The copyright holder for this preprint (which was not certified by peer review) is the author/funder, who has granted medRxiv a license to display the preprint in perpetuity.

All rights reserved. No reuse allowed without permission.

The sleep-wake detection performance at-home of the Happy Personalized and Happy Generalized algorithms, along with those of Oura, Whoop, Fitbit, and Actiwatch devices are presented in Table 4. The overall accuracy for the Happy devices was $0.92(\mathrm{SD}=0.04)$ for the Happy Personalized algorithm and 0.91 $(\mathrm{SD}=0.04)$ for the Happy Generalized algorithm. Values for sleep-wake detection accuracy at home for other devices were $0.92(\mathrm{SD}=0.03)$ for Oura, $0.89(\mathrm{SD}=0.08)$ for Whoop, $0.89(\mathrm{SD}=0.04)$ for Fitbit, and $0.89(\mathrm{SD}=0.03)$ for Actiwatch. Specificity, sensitivity, positive predictive value and negative predictive values for sleep-wake detection for these devices are also reported in Table 4.

For data collected at home, TST estimates, relative to PSG values, are depicted in Figure 3D, and differences in WASO across devices are reported in Figure 3E. Figure 3F shows differences for sleep stages across devices. Bland-Altman plots comparing the Happy Generalized and Happy Personalized algorithms were computed. Data comparing these algorithms relative to sleep continuity and sleep stages are reported in supplementary figures S3 and S4.

\section{Confusion Matrices}

Confusion matrices are depicted in Figure 4. Figure 4A depicts the 4-stage confusion matrix comparing Happy Generalized and in-lab polysomnography. Figure 4B depicts the confusion matrix for Happy Personalized and in-lab polysomnography. Figures 4C and 4D depict the confusion matrices for Happy Generalized and Happy Personalized at home, respectively. Due to unbalanced classes, two metrics are computed for each confusion matrix. First the number of each prediction corresponding to a specific true-predicted pair is reported. Second, the color indicates the scaled probability of occurrence of a specific pair, hence artificially removing class imbalance. The title in each plot shows the average classification accuracy across all sleep stages. 
medRxiv preprint doi: https://doi.org/10.1101/2021.12.22.21268267; this version posted January 1, 2022. The copyright holder for this preprint (which was not certified by peer review) is the author/funder, who has granted medRxiv a license to display the preprint in perpetuity.

All rights reserved. No reuse allowed without permission.

\section{DISCUSSION}

The present study evaluated the performance of the Happy Ring for the evaluation of sleep continuity and sleep architecture among healthy working-age adults, using two different scoring approaches - generalized and personalized. Compared to both at-home and laboratory polysomnography, the generalized strategy demonstrated good sensitivity and moderate specificity, similar to other, comparable devices that have been previously empirically evaluated. The personalized strategy maintained a high level of sensitivity, but demonstrated improved specificity relative to the other devices studied $(P<.001)$. Regarding sleep staging, the rate of agreement between the Happy Ring and both home and laboratory polysomnography for light, deep, and REM sleep was moderate, similar to other sleep-tracking devices to which it was compared. The personalized approach, again, demonstrated improved accuracy for discernment of sleep stages $(P<.001)$. Taken together, the Happy Ring demonstrated good performance for the detection of sleep versus wake, relative to both home and laboratory polysomnography, in line with other devices that also use movement and heart rate to evaluate sleep. Further, the personalized scoring approach consistently performed better than the generalized approach.

The main finding from this work is that, among generally healthy adults, the Happy Ring performs preferably in terms of discerning sleep versus wake when compared to other similar devices in both a lab and an at-home setting. The degree of sensitivity (93-94\%) was similar to the other devices that were evaluated $(89-94 \%)$. This is in line with previous work, which shows that these and similar devices typically demonstrate sensitivity over $90 \%{ }^{28,45}$. However, it should be noted that the sensitivity found for some of the comparison devices in this study were a few percentage points below that seen in previously published studies using those same devices. This finding could be a result of a myriad of factors, such as a more diverse sample in the present study, the presence of an at-home component of the protocol, or it may be a result of other factors. When multiple previously established devices are compared in the same study, sensitivity values are often similar ${ }^{28}$. 
medRxiv preprint doi: https://doi.org/10.1101/2021.12.22.21268267; this version posted January 1, 2022. The copyright holder for this preprint (which was not certified by peer review) is the author/funder, who has granted medRxiv a license to display the preprint in perpetuity. All rights reserved. No reuse allowed without permission.

When evaluating sleep-wake detection, specificity refers to the ability of a device to detect wakefulness in the context of otherwise continuous sleep. This is the parameter for which current devices tend to perform

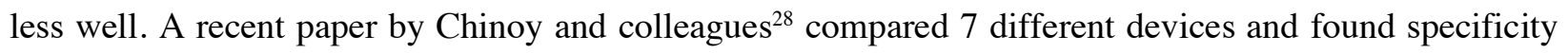
values between $18-54 \%$. These findings are similar to those observed in the present study, which found values ranging from $19-54 \%$ across previously-studied devices relative to in-laboratory polysomnography. The Happy generalized performed nominally better, with 70\% specificity. The Happy personalized approach demonstrated statistically significantly improved performance, with a mean specificity of $83 \%$. This suggests that the personalized approach may be a strategy for improving sleep-wake detection by improving the ability of the device to discern wake epochs. This is especially important for the evaluation of relatively healthy sleepers, as most healthy sleepers will achieve a sleep efficiency of over $90 \%{ }^{48}$. If a device simply scores every epoch as sleep, with no discernment or algorithm, it will appear to have $90 \%$ accuracy. In this case, it would have $100 \%$ sensitivity but $0 \%$ specificity. For a consumer device that will presumably be used to assess sleep in individuals with a generally high sleep efficiency, therefore, higher specificity is perhaps more important than overall accuracy because of the skewed nature of sleep-wake data in healthy populations. For this reason, the improved specificity of the Happy personalized approach may represent a significant innovation that can improve the utility of wearable sleep assessments.

Regarding sleep stages, the Happy Ring performed relatively well at discerning light (stages N1 and N2) deep (stage N3), and REM sleep. Previous studies have shown that peripheral data from heart rate and movement can be used to approximate sleep stages, but these algorithms are still limited in providing more than a general approximation ${ }^{30,49}$. For this reason, peripherally scored sleep staging data are still insufficient for replacing sleep stages derived from polysomnography. Regardless, values from at-home sleep tracking devices can be useful, especially as they can be sampled over many days and in large numbers of people, unlike polysomnography ${ }^{9,11}$. The performance of the Happy Generalized model performed about the same as other similar devices on the market. In addition, as with sleep-wake determination, the Happy Personalized model performed preferably to other comparable devices for sleep stage classification. 
medRxiv preprint doi: https://doi.org/10.1101/2021.12.22.21268267; this version posted January 1, 2022. The copyright holder for this preprint (which was not certified by peer review) is the author/funder, who has granted medRxiv a license to display the preprint in perpetuity.

All rights reserved. No reuse allowed without permission.

The first actigraphy scoring studies used hand scoring ${ }^{50}$. Soon afterwards, scoring algorithms were introduced $^{51}$ and subsequently refined ${ }^{52,53}$. These algorithms started as basic prediction equations that used weighted values from the epoch of interest and multiple epochs in the past or future to determine, based on movement, if an individual is awake or asleep ${ }^{52,53,54}$. Over time, and with the inclusion of other signals like heart rate, these algorithms have become more complex ${ }^{28,41}$. A more recent advance is the use of machine learning to not only derive an optimal scoring algorithm based on a specific signal, but also as part of a strategy to combine multiple signals ${ }^{4,32,33}$. Although this approach has demonstrated improvements over older approaches, there is still the limitation that the algorithm itself remains largely static and generalized to the population, rather than to the individual. However, with the advent of improved computing power, it is possible to develop an algorithm that is dynamic and changes based on the users' own data. This personalization is the difference between the Happy Generalized and Personalized approaches. The generalized approach, as evaluated in this study, represents a relatively static algorithm that is universally applied to all records, which is the standard approach across other devices. Since a generalized approach is functionally similar to the algorithms in the other studied devices, it is unsurprising that this algorithm performs comparably well. The personalized approach, however, represents a potential innovation, in that it starts with generalized parameters but changes over time based on use. As the user wears the device over multiple subsequent recording periods, the algorithm modifies itself in response to the parameters obtained by that user. Thus, the scoring algorithm is fluid and unique across users, based on their own data. This approach - a dynamic, personalized algorithm - demonstrated the best performance both in the lab and at home, especially for the key parameter of specificity. Future algorithm development for sleep wearables may be improved by including an individualized scoring component.

This study had several unique strengths. Objective polysomnographic sleep was assessed both in the laboratory and at home, under naturalistic conditions. Further, the performance of the Happy Ring was assessed relative to other types of devices, including standard actigraphy (i.e., Actiwatch), wrist-worn multisensory device (i.e., Fitbit, Whoop), and ring-worn multisensory device (i.e., Oura). The design of the study and the 
medRxiv preprint doi: https://doi.org/10.1101/2021.12.22.21268267; this version posted January 1, 2022. The copyright holder for this preprint (which was not certified by peer review) is the author/funder, who has granted medRxiv a license to display the preprint in perpetuity.

All rights reserved. No reuse allowed without permission.

subsequent analytic methods were aligned with recent guidelines and recommendations for sleep-tracking device evaluation ${ }^{9,10}$.

However, the study did have some limitations. The sample size was relatively small and consisted of generally healthy adults, which may limit generalizability of the findings. Future research in evaluation of the Happy Ring and associated sleep algorithms will aim to collect data from a wider, more diverse population. Additionally, the home-based polysomnography recordings were obtained using a commercial device (i.e., Dreem) rather than a traditional laboratory device. Lastly, the algorithms underlying the Happy Generalized and Happy Personalized scoring strategies are not transparent and rely on undisclosed factors.

In conclusion, the present study describes the initial development and assessment of the Happy Ring, a novel device for the assessment of sleep continuity and architecture. Overall, the device performed well, demonstrating good sensitivity and moderate specificity. When compared to other consumer sleep-tracking devices, the Happy Generalized scoring procedure demonstrated comparable performance for sleep-wake detection and sleep stage classification; while the novel Happy Personalized algorithm

Demonstrated moderate improvement in performance compared to other devices studied. Future research should examine the performance of this device in other contexts and larger samples. In addition, future work should explore the value of additional peripheral signals to the assessment of sleep in the context of overall health and wellbeing. Finally, the improved performance of the Happy Personalized algorithm suggests that sleep assessment using wearables can be improved by developing more dynamic and adaptable algorithms that leverage user data prospectively. 
medRxiv preprint doi: https://doi.org/10.1101/2021.12.22.21268267; this version posted January 1, 2022. The copyright holder for this preprint

(which was not certified by peer review) is the author/funder, who has granted medRxiv a license to display the preprint in perpetuity.

All rights reserved. No reuse allowed without permission.

\section{REFERENCES}

1. Depner CM, Stothard ER, Wright KP. Metabolic Consequences of Sleep and Circadian Disorders. Curr Diab Rep. 2014;14(7):507. doi:10.1007/s11892-014-0507-z

2. Baglioni C, Nanovska S, Regen W, et al. Sleep and mental disorders: A meta-analysis of polysomnographic research. Psychol Bull. 2016;142(9):969-990. doi:10.1037/bul0000053

3. Luyster FS, Strollo PJ, Zee PC, Walsh JK. Sleep: A Health Imperative. Sleep. 2012;35(6):727-734. doi:10.5665/sleep.1846

4. Perez-Pozuelo I, Zhai B, Palotti J, et al. The future of sleep health: a data-driven revolution in sleep science and medicine. Npj Digit Med. 2020;3(1):42. doi:10.1038/s41746-020-0244-4

5. Grandner MA. Sleep, Health, and Society. Sleep Med Clin. 2017;12(1):1-22.

doi:10.1016/j.jsmc.2016.10.012

6. Grandner MA, Fernandez FX. The translational neuroscience of sleep: A contextual framework. Science. 2021;374(6567):568-573. doi:10.1126/science.abj8188

7. Marino M, Li Y, Rueschman MN, et al. Measuring Sleep: Accuracy, Sensitivity, and Specificity of Wrist Actigraphy Compared to Polysomnography. Sleep. 2013;36(11):1747-1755.

doi:10.5665/sleep.3142

8. Baron KG, Duffecy J, Berendsen MA, Cheung Mason I, Lattie EG, Manalo NC. Feeling validated yet? A scoping review of the use of consumer-targeted wearable and mobile technology to measure and improve sleep. Sleep Med Rev. 2018;40:151-159. doi:10.1016/j.smrv.2017.12.002

9. De Zambotti M, Cellini N, Goldstone A, Colrain IM, Baker FC. Wearable Sleep Technology in Clinical and Research Settings. Med Sci Sports Exerc. 2019;51(7):1538-1557.

doi:10.1249/MSS.0000000000001947

10. Menghini L, Cellini N, Goldstone A, Baker FC, de Zambotti M. A standardized framework for testing the performance of sleep-tracking technology: step-by-step guidelines and open-source code. Sleep. 2021;44(2):zsaa170. doi:10.1093/sleep/zsaa170

11. Lujan MR, Perez-Pozuelo I, Grandner MA. Past, Present, and Future of Multisensory Wearable Technology to Monitor Sleep and Circadian Rhythms. Front Digit Health. 2021;3:721919. doi:10.3389/fdgth.2021.721919

12. Teo JX, Davila S, Yang C, et al. Digital phenotyping by consumer wearables identifies sleep-associated markers of cardiovascular disease risk and biological aging. Commun Biol. 2019;2(1):361. doi:10.1038/s42003-019-0605-1

13. Baron KG, Reid KJ, Malkani RG, Kang J, Zee PC. Sleep Variability Among Older Adults With Insomnia: Associations With Sleep Quality and Cardiometabolic Disease Risk. Behav Sleep Med. 2017;15(2):144-157. doi:10.1080/15402002.2015.1120200 
medRxiv preprint doi: https://doi.org/10.1101/2021.12.22.21268267; this version posted January 1, 2022. The copyright holder for this preprint

(which was not certified by peer review) is the author/funder, who has granted medRxiv a license to display the preprint in perpetuity.

All rights reserved. No reuse allowed without permission.

14. Turel O, Romashkin A, Morrison KM. Health Outcomes of Information System Use Lifestyles among Adolescents: Videogame Addiction, Sleep Curtailment and Cardio-Metabolic Deficiencies. Folli F, ed. PLOS ONE. 2016;11(5):e0154764. doi:10.1371/journal.pone.0154764

15. Park H, Tsai KM, Dahl RE, et al. Sleep and Inflammation During Adolescence. Psychosom Med. 2016;78(6):677-685. doi:10.1097/PSY.0000000000000340

16. Reynold AM, Bowles ER, Saxena A, Fayad R. Negative Effects of Time in Bed Extension: A Pilot Study. 2014:13.

17. Benard V, Etain B, Vaiva G, et al. Sleep and circadian rhythms as possible trait markers of suicide attempt in bipolar disorders: An actigraphy study. J Affect Disord. 2019;244:1-8.

doi:10.1016/j.jad.2018.09.054

18. Moshe I, Terhorst Y, Opoku Asare K, et al. Predicting Symptoms of Depression and Anxiety Using Smartphone and Wearable Data. Front Psychiatry. 2021;12:625247. doi:10.3389/fpsyt.2021.625247

19. Peacock C, Mena M, Sanders G, Silver T, Kalman D, Antonio J. Sleep Data, Physical Performance, and Injuries in Preparation for Professional Mixed Martial Arts. Sports. 2018;7(1):1.

doi:10.3390/sports 7010001

20. Smirnova E, Leroux A, Cao Q, et al. The Predictive Performance of Objective Measures of Physical Activity Derived From Accelerometry Data for 5-Year All-Cause Mortality in Older Adults: National Health and Nutritional Examination Survey 2003-2006. Newman A, ed. J Gerontol Ser A. 2020;75(9):1779-1785. doi:10.1093/gerona/glz193

21. de Zambotti M, Cellini N, Menghini L, Sarlo M, Baker FC. Sensors Capabilities, Performance, and Use of Consumer Sleep Technology. Sleep Med Clin. 2020;15(1):1-30.

doi:10.1016/j.jsmc.2019.11.003

22. Lionel Sujay Vailshery. Topic: Fitness trackers. Statista. https://www.statista.com/topics/4393/fitness-and-activity-tracker/. Accessed December 15, 2021.

23. Sadeh A. The role and validity of actigraphy in sleep medicine: An update. Sleep Med Rev. 2011;15(4):259-267. doi:10.1016/j.smrv.2010.10.001

24. Paquet J, Kawinska A, Carrier J. Wake Detection Capacity of Actigraphy During Sleep. Sleep. 2007;30(10):1362-1369. doi:10.1093/sleep/30.10.1362

25. Ancoli-Israel S, Cole R, Alessi C, Chambers M, Moorcroft W, Pollak CP. The Role of Actigraphy in the Study of Sleep and Circadian Rhythms. Sleep. 2003;26(3):342-392.

doi:10.1093/sleep/26.3.342

26. Tal A, Shinar Z, Shaki D, Codish S, Goldbart A. Validation of Contact-Free Sleep Monitoring Device with Comparison to Polysomnography. J Clin Sleep Med. 2017;13(03):517-522.

doi:10.5664/jcsm. 6514

27. Lee XK, Chee NIYN, Ong JL, et al. Validation of a Consumer Sleep Wearable Device With Actigraphy and Polysomnography in Adolescents Across Sleep Opportunity Manipulations. J Clin Sleep Med. 2019;15(09):1337-1346. doi:10.5664/jcsm.7932 
medRxiv preprint doi: https://doi.org/10.1101/2021.12.22.21268267; this version posted January 1, 2022. The copyright holder for this preprint

(which was not certified by peer review) is the author/funder, who has granted medRxiv a license to display the preprint in perpetuity.

All rights reserved. No reuse allowed without permission.

28. Chinoy ED, Cuellar JA, Huwa KE, et al. Performance of seven consumer sleep-tracking devices compared with polysomnography. Sleep. 2021;44(5):zsaa291. doi:10.1093/sleep/zsaa291

29. Grandner MA, Lujan MR, Ghani SB. Sleep-tracking technology in scientific research: looking to the future. Sleep. 2021;44(5):zsab071. doi:10.1093/sleep/zsab071

30. Moreno-Pino F, Porras-Segovia A, López-Esteban P, Artés A, Baca-García E. Validation of Fitbit Charge 2 and Fitbit Alta HR Against Polysomnography for Assessing Sleep in Adults With Obstructive Sleep Apnea. J Clin Sleep Med. 2019;15(11):1645-1653. doi:10.5664/jcsm.8032

31. Walch O, Huang Y, Forger D, Goldstein C. Sleep stage prediction with raw acceleration and photoplethysmography heart rate data derived from a consumer wearable device. Sleep.

2019;42(12):zsz180. doi:10.1093/sleep/zsz180

32. Haghayegh S, Khoshnevis S, Smolensky MH, Diller KR. Application of deep learning to improve sleep scoring of wrist actigraphy. Sleep Med. 2020;74:235-241. doi:10.1016/j.sleep.2020.05.008

33. Palotti J, Mall R, Aupetit M, et al. Benchmark on a large cohort for sleep-wake classification with machine learning techniques. Npj Digit Med. 2019;2(1):50. doi:10.1038/s41746-019-0126-9

34. Depner CM, Cheng PC, Devine JK, et al. Wearable technologies for developing sleep and circadian biomarkers: a summary of workshop discussions. Sleep. 2020;43(2):zsz254. doi:10.1093/sleep/zsz254

35. Greiwe J, Nyenhuis SM. Wearable Technology and How This Can Be Implemented into Clinical Practice. Curr Allergy Asthma Rep. 2020;20(8):36. doi:10.1007/s11882-020-00927-3

36. Nguyen QNT, Le T, Huynh QBT, Setty A, Vo TV, Le TQ. Validation Framework for Sleep Stage Scoring in Wearable Sleep Trackers and Monitors with Polysomnography Ground Truth. Clocks Sleep. 2021;3(2):274-288. doi:10.3390/clockssleep3020017

37. AASM Scoring Manual - American Academy of Sleep Medicine. Am Acad Sleep Med - Assoc Sleep Clin Res. https://aasm.org/clinical-resources/scoring-manual/. Accessed December 15, 2021.

38. Arnal PJ, Thorey V, Debellemaniere E, et al. The Dreem Headband compared to polysomnography for electroencephalographic signal acquisition and sleep staging. Sleep. 2020;43(11):zsaa097. doi:10.1093/sleep/zsaa097

39. Montgomery-Downs HE, Insana SP, Bond JA. Movement toward a novel activity monitoring device. Sleep Breath. 2012;16(3):913-917. doi:10.1007/s11325-011-0585-y

40. Stucky B, Clark I, Azza Y, et al. Validation of Fitbit Charge 2 Sleep and Heart Rate Estimates Against Polysomnographic Measures in Shift Workers: Naturalistic Study. J Med Internet Res. 2021;23(10):e26476. doi:10.2196/26476

41. Beattie Z, Oyang Y, Statan A, et al. Estimation of sleep stages in a healthy adult population from optical plethysmography and accelerometer signals. Physiol Meas. 2017;38(11):1968-1979. doi:10.1088/1361-6579/aa9047

42. Miller DJ, Roach GD, Lastella M, et al. A Validation Study of a Commercial Wearable Device to Automatically Detect and Estimate Sleep. Biosensors. 2021;11(6):185. doi:10.3390/bios11060185 
medRxiv preprint doi: https://doi.org/10.1101/2021.12.22.21268267; this version posted January 1, 2022. The copyright holder for this preprint (which was not certified by peer review) is the author/funder, who has granted medRxiv a license to display the preprint in perpetuity. All rights reserved. No reuse allowed without permission.

43. Berryhill S, Morton CJ, Dean A, et al. Effect of wearables on sleep in healthy individuals: a randomized crossover trial and validation study. J Clin Sleep Med. 2020;16(5):775-783. doi: $10.5664 / j \operatorname{csm} .8356$

44. de Zambotti M, Rosas L, Colrain IM, Baker FC. The Sleep of the Ring: Comparison of the ŌURA Sleep Tracker Against Polysomnography. Behav Sleep Med. 2019;17(2):124-136. doi:10.1080/15402002.2017.1300587

45. Duda, RO, Hart, PE, \& Stork, DG. Pattern classification (2nd ed.). New York: Wiley; 2000.

46.Bishop, C. Pattern Recognition and Machine Learning. Springer, 2006.

47. Van De Water ATM, Holmes A, Hurley DA. Objective measurements of sleep for non-laboratory settings as alternatives to polysomnography - a systematic review: A systematic review of objective sleep measures. J Sleep Res. 2011;20(1pt2):183-200. doi:10.1111/j.1365-2869.2009.00814.x

48. Mitterling T, Högl B, Schönwald SV, et al. Sleep and Respiration in 100 Healthy Caucasian Sleepers-A Polysomnographic Study According to American Academy of Sleep Medicine Standards. SLEEP. June 2015. doi:10.5665/sleep.4730

49. Kahawage P, Jumabhoy R, Hamill K, Zambotti M, Drummond SPA. Validity, potential clinical utility, and comparison of consumer and research-grade activity trackers in Insomnia Disorder I: In-lab validation against polysomnography. J Sleep Res. 2020;29(1). doi:10.1111/jsr.12931

50. Mullaney DJ, Kripke DF, Messin S. Wrist-Actigraphic Estimation of Sleep Time. Sleep. 1980;3(1):83-92. doi:10.1093/sleep/3.1.83

51. Webster JB, Kripke DF, Messin S, Mullaney DJ, Wyborney G. An Activity-Based Sleep Monitor System for Ambulatory Use. Sleep. 1982;5(4):389-399. doi:10.1093/sleep/5.4.389

52. Cole RJ, Kripke DF, Gruen W, Mullaney DJ, Gillin JC. Automatic Sleep/Wake Identification From Wrist Activity. Sleep. 1992;15(5):461-469. doi:10.1093/sleep/15.5.461

53. Sadeh A, Sharkey M, Carskadon MA. Activity-Based Sleep-Wake Identification: An Empirical Test of Methodological Issues. Sleep. 1994;17(3):201-207. doi:10.1093/sleep/17.3.201

54. de Souza L, Benedito-Silva AA, Pires MLN, Poyares D, Tufik S, Calil HM. Further Validation of Actigraphy for Sleep Studies. Sleep. 2003;26(1):81-85. doi:10.1093/sleep/26.1.81 
medRxiv preprint doi: https://doi.org/10.1101/2021.12.22.21268267; this version posted January 1, 2022. The copyright holder for this preprint (which was not certified by peer review) is the author/funder, who has granted medRxiv a license to display the preprint in perpetuity.

All rights reserved. No reuse allowed without permission.

\section{List of Abbreviations}

\begin{tabular}{lr}
\hline Abbreviation & Meaning \\
EDA & Electrodermal Activity \\
PPG & Photoplethysmography \\
Hz & Hertz, cycles per second \\
TIB & Time in Bed \\
SL & Sleep Latency \\
WASO & Wake After Sleep Onset \\
TST & Total Sleep Time \\
NREM & Non-Rapid Eye Movement \\
Stage N1 & Light Sleep \\
Stage N2 & Light Sleep \\
Stage N3 & Deep Sleep \\
PSG & Polysomnography \\
REM & Rapid Eye Movement \\
PPV & Positive Predictive Value \\
NPV & Negative Predictive Value \\
EEG & Electroencephalogram \\
EKG & Electrocardiogram \\
EOG & Electroocoulogram \\
EMG & Electromyogram
\end{tabular}


medRxiv preprint doi: https://doi.org/10.1101/2021.12.22.21268267; this version posted January 1, 2022. The copyright holder for this preprint (which was not certified by peer review) is the author/funder, who has granted medRxiv a license to display the preprint in perpetuity.

All rights reserved. No reuse allowed without permission.

\section{Table 1. Characteristics of the Sample}

\begin{tabular}{|c|c|c|}
\hline Variable & Category/Units & Values \\
\hline $\mathbf{N}$ & Subjects & $\mathrm{N}=36$ \\
\hline \multirow{2}{*}{ Sex } & Male & $55.6 \%$ \\
\hline Age & Female & $44.4 \%$ \\
\cline { 2 - 3 } Body Mass Index & Years & $23.4(\mathrm{SD}=3.8)$ \\
\hline \multirow{4}{*}{ Race/Ethnicity } & $\mathrm{Kg} / \mathrm{m} 2$ & $23.4(\mathrm{SD}=3.8)$ \\
\hline & Non-Hispanic White & $25(69.4 \%)$ \\
\cline { 2 - 3 } & Hispanic/Latino & $3(8.3 \%)$ \\
\cline { 2 - 3 } & Asian/Asian American & $6(16.7 \%)$ \\
\cline { 2 - 3 } & Other/Unknown & $2(5.6 \%)$ \\
\hline
\end{tabular}


medRxiv preprint doi: https://doi.org/10.1101/2021.12.22.21268267; this version posted January 1, 2022. The copyright holder for this preprint (which was not certified by peer review) is the author/funder, who has granted medRxiv a license to display the preprint in perpetuity.

All rights reserved. No reuse allowed without permission.

Table 2. Sleep-Wake Detection of Studied Devices Compared to In-Lab Polysomnography

\begin{tabular}{|c|c|c|c|c|c|c|}
\hline & Personalized & Generalized & Oura & Whoop & Fitbit & Actiwatch \\
\hline $\mathbf{N}$ & $33(33)$ & $33(33)$ & $30(30)$ & $33(33)$ & $27(27)$ & $26(26)$ \\
\hline Accuracy & $0.92+/-0.04$ & $0.91+/-0.04$ & $0.88+/-0.05$ & $0.86+/-0.05$ & $0.84+/-0.07$ & $0.85+/-0.07$ \\
\hline Sensitivity & $0.93+/-0.04$ & $0.94+/-0.04$ & $0.93+/-0.05$ & $0.9+/-0.05$ & $0.89+/-0.09$ & $0.94+/-0.03$ \\
\hline Specificity & $0.83+/-0.11$ & $0.70+/-0.18$ & $0.49+/-0.22$ & $0.54+/-0.18$ & $0.49+/-0.18$ & $0.19+/-0.12$ \\
\hline PPV & $0.97+/-0.02$ & $0.96+/-0.03$ & $0.94+/-0.04$ & $0.93+/-0.05$ & $0.92+/-0.05$ & $0.89+/-0.07$ \\
\hline NPV & $0.61+/-0.23$ & $0.61+/-0.25$ & $0.48+/-0.20$ & $0.45+/-0.21$ & $0.39+/-0.18$ & $0.33+/-0.21$ \\
\hline
\end{tabular}


medRxiv preprint doi: https://doi.org/10.1101/2021.12.22.21268267; this version posted January 1, 2022. The copyright holder for this preprint (which was not certified by peer review) is the author/funder, who has granted medRxiv a license to display the preprint in perpetuity. All rights reserved. No reuse allowed without permission.

Table 3. Sleep Stage Detection with Studied Devices Compared to In-Lab Polysomnography

\begin{tabular}{|c|c|c|c|c|c|}
\hline & Personalized & Generalized & Oura & Whoop & Fitbit \\
\hline N & $33(33)$ & $33(33)$ & $30(30)$ & $33(33)$ & $27(27)$ \\
\hline \multicolumn{7}{|c|}{ Awake } \\
\hline Accuracy & $0.92+/-0.04$ & $0.91+/-0.04$ & $0.88+/-0.05$ & $0.86+/-0.05$ & $0.84+/-0.07$ \\
\hline Sensitivity & $0.83+/-0.11$ & $0.70+/-0.18$ & $0.49+/-0.22$ & $0.54+/-0.18$ & $0.49+/-0.18$ \\
\hline Specificity & $0.93+/-0.04$ & $0.94+/-0.04$ & $0.93+/-0.05$ & $0.90+/-0.05$ & $0.89+/-0.09$ \\
\hline PPV & $0.61+/-0.23$ & $0.61+/-0.25$ & $0.48+/-0.2$ & $0.45+/-0.21$ & $0.39+/-0.18$ \\
\hline NPV & $0.97+/-0.02$ & $0.96+/-0.03$ & $0.94+/-0.04$ & $0.93+/-0.05$ & $0.92+/-0.05$ \\
\hline \multicolumn{7}{|c|}{ Light } \\
\hline Accuracy & $0.81+/-0.06$ & $0.67+/-0.07$ & $0.61+/-0.09$ & $0.59+/-0.06$ & $0.65+/-0.07$ \\
\hline Sensitivity & $0.73+/-0.12$ & $0.61+/-0.11$ & $0.57+/-0.14$ & $0.49+/-0.09$ & $0.64+/-0.12$ \\
\hline Specificity & $0.91+/-0.05$ & $0.76+/-0.13$ & $0.64+/-0.13$ & $0.71+/-0.10$ & $0.66+/-0.13$ \\
\hline PPV & $0.92+/-0.05$ & $0.79+/-0.10$ & $0.69+/-0.08$ & $0.71+/-0.08$ & $0.73+/-0.07$ \\
\hline NPV & $0.71+/-0.1$ & $0.58+/-0.10$ & $0.53+/-0.12$ & $0.50+/-0.08$ & $0.57+/-0.11$ \\
\hline \multicolumn{7}{|c|}{ Deep } \\
\hline Accuracy & $0.95+/-0.03$ & $0.85+/-0.06$ & $0.81+/-0.08$ & $0.82+/-0.05$ & $0.86+/-0.04$ \\
\hline Sensitivity & $0.89+/-0.19$ & $0.7+/-0.26$ & $0.6+/-0.26$ & $0.56+/-0.19$ & $0.48+/-0.26$ \\
\hline Specificity & $0.95+/-0.03$ & $0.87+/-0.07$ & $0.83+/-0.10$ & $0.85+/-0.05$ & $0.91+/-0.05$ \\
\hline PPV & $0.67+/-0.18$ & $0.38+/-0.22$ & $0.35+/-0.17$ & $0.34+/-0.2$ & $0.40+/-0.30$ \\
\hline NPV & $0.99+/-0.01$ & $0.96+/-0.04$ & $0.94+/-0.04$ & $0.94+/-0.04$ & $0.94+/-0.04$ \\
\hline \multicolumn{7}{|c|}{ REM } \\
\hline Accuracy & $0.92+/-0.04$ & $0.85+/-0.05$ & $0.84+/-0.05$ & $0.81+/-0.07$ & $0.86+/-0.05$ \\
\hline Sensitivity & $0.89+/-0.08$ & $0.67+/-0.21$ & $0.51+/-0.21$ & $0.65+/-0.19$ & $0.61+/-0.17$ \\
\hline Specificity & $0.92+/-0.05$ & $0.89+/-0.07$ & $0.91+/-0.05$ & $0.85+/-0.08$ & $0.91+/-0.05$ \\
\hline PPV & $0.72+/-0.12$ & $0.58+/-0.17$ & $0.55+/-0.14$ & $0.49+/-0.18$ & $0.6+/-0.16$ \\
\hline NPV & $0.98+/-0.02$ & $0.93+/-0.05$ & $0.90+/-0.04$ & $0.92+/-0.04$ & $0.92+/-0.04$ \\
\hline \multicolumn{7}{|c|}{ All Stages } \\
\hline Sensitivity & $0.80+/-0.07$ & $0.64+/-0.07$ & $0.57+/-0.09$ & $0.54+/-0.08$ & $0.61+/-0.07$ \\
\hline Kappa & $0.68+/-0.09$ & $0.45+/-0.11$ & $0.32+/-0.13$ & $0.32+/-0.10$ & $0.37+/-0.13$ \\
\hline
\end{tabular}


medRxiv preprint doi: https://doi.org/10.1101/2021.12.22.21268267; this version posted January 1, 2022. The copyright holder for this preprint (which was not certified by peer review) is the author/funder, who has granted medRxiv a license to display the preprint in perpetuity.

All rights reserved. No reuse allowed without permission.

Table 4. Sleep-Wake Detection with Studied Devices Compared to Home Polysomnography

\begin{tabular}{|c|c|c|c|c|c|c|}
\hline & Personalized & Generalized & Oura & Whoop & Fitbit & Actiwatch \\
\hline N & $40(26)$ & $40(26)$ & $29(19)$ & $31(20)$ & $25(17)$ & $30(20)$ \\
\hline Accuracy & $0.92+/-0.04$ & $0.91+/-0.04$ & $0.92+/-0.03$ & $0.89+/-0.08$ & $0.89+/-0.04$ & $0.89+/-0.03$ \\
\hline Sensitivity & $0.93+/-0.04$ & $0.94+/-0.05$ & $0.96+/-0.03$ & $0.91+/-0.09$ & $0.92+/-0.05$ & $0.94+/-0.02$ \\
\hline Specificity & $0.75+/-0.11$ & $0.67+/-0.11$ & $0.59+/-0.13$ & $0.59+/-0.21$ & $0.60+/-0.13$ & $0.41+/-0.12$ \\
\hline PPV & $0.97+/-0.01$ & $0.96+/-0.03$ & $0.96+/-0.02$ & $0.96+/-0.02$ & $0.96+/-0.03$ & $0.93+/-0.04$ \\
\hline NPV & $0.54+/-0.18$ & $0.55+/-0.2$ & $0.59+/-0.18$ & $0.49+/-0.20$ & $0.44+/-0.16$ & $0.42+/-0.17$ \\
\hline
\end{tabular}


medRxiv preprint doi: https://doi.org/10.1101/2021.12.22.21268267; this version posted January 1, 2022. The copyright holder for this preprint (which was not certified by peer review) is the author/funder, who has granted medRxiv a license to display the preprint in perpetuity. All rights reserved. No reuse allowed without permission.

Table 5. Sleep Stage with Studied Devices Compared to Home Polysomnography

\begin{tabular}{|c|c|c|c|c|c|}
\hline & \multirow{2}{*}{ Personalized } & \multirow{2}{*}{ Generalized } & Oura & Whoop & Fitbit \\
\hline N & $40(26)$ & $40(26)$ & $29(19)$ & $31(20)$ & $25(17)$ \\
\hline \multicolumn{7}{|c|}{ Awake } \\
\hline Accuracy & $0.92+/-0.04$ & $0.91+/-0.04$ & $0.92+/-0.03$ & $0.89+/-0.08$ & $0.89+/-0.04$ \\
\hline Sensitivity & $0.75+/-0.11$ & $0.67+/-0.11$ & $0.59+/-0.13$ & $0.59+/-0.21$ & $0.6+/-0.13$ \\
\hline Specificity & $0.93+/-0.04$ & $0.94+/-0.05$ & $0.96+/-0.03$ & $0.91+/-0.09$ & $0.92+/-0.05$ \\
\hline PPV & $0.54+/-0.18$ & $0.55+/-0.20$ & $0.59+/-0.18$ & $0.49+/-0.20$ & $0.44+/-0.16$ \\
\hline NPV & $0.97+/-0.01$ & $0.96+/-0.03$ & $0.96+/-0.02$ & $0.96+/-0.02$ & $0.96+/-0.03$ \\
\hline \multicolumn{7}{|c|}{ Light } \\
\hline Accuracy & $0.78+/-0.05$ & $0.66+/-0.08$ & $0.67+/-0.07$ & $0.67+/-0.09$ & $0.7+/-0.10$ \\
\hline Sensitivity & $0.68+/-0.14$ & $0.58+/-0.17$ & $0.68+/-0.13$ & $0.66+/-0.15$ & $0.73+/-0.11$ \\
\hline Specificity & $0.82+/-0.11$ & $0.70+/-0.16$ & $0.65+/-0.14$ & $0.69+/-0.11$ & $0.67+/-0.13$ \\
\hline PPV & $0.75+/-0.11$ & $0.60+/-0.13$ & $0.58+/-0.10$ & $0.58+/-0.12$ & $0.62+/-0.12$ \\
\hline NPV & $0.80+/-0.06$ & $0.72+/-0.11$ & $0.75+/-0.08$ & $0.76+/-0.09$ & $0.78+/-0.10$ \\
\hline \multicolumn{7}{|c|}{ Deep } \\
\hline Accuracy & $0.92+/-0.03$ & $0.83+/-0.05$ & $0.84+/-0.05$ & $0.86+/-0.06$ & $0.84+/-0.08$ \\
\hline Sensitivity & $0.69+/-0.25$ & $0.70+/-0.22$ & $0.63+/-0.32$ & $0.59+/-0.17$ & $0.56+/-0.26$ \\
\hline Specificity & $0.96+/-0.03$ & $0.88+/-0.07$ & $0.89+/-0.08$ & $0.95+/-0.04$ & $0.94+/-0.06$ \\
\hline PPV & $0.85+/-0.12$ & $0.61+/-0.21$ & $0.64+/-0.19$ & $0.78+/-0.15$ & $0.71+/-0.26$ \\
\hline NPV & $0.93+/-0.04$ & $0.91+/-0.07$ & $0.90+/-0.07$ & $0.88+/-0.07$ & $0.87+/-0.09$ \\
\hline \multicolumn{7}{|c|}{ REM } \\
\hline Accuracy & $0.85+/-0.06$ & $0.78+/-0.09$ & $0.82+/-0.05$ & $0.83+/-0.08$ & $0.86+/-0.06$ \\
\hline Sensitivity & $0.74+/-0.16$ & $0.51+/-0.24$ & $0.52+/-0.16$ & $0.63+/-0.23$ & $0.63+/-0.16$ \\
\hline Specificity & $0.88+/-0.08$ & $0.89+/-0.09$ & $0.93+/-0.04$ & $0.91+/-0.05$ & $0.94+/-0.03$ \\
\hline PPV & $0.73+/-0.10$ & $0.65+/-0.16$ & $0.74+/-0.16$ & $0.67+/-0.21$ & $0.75+/-0.19$ \\
\hline NPV & $0.91+/-0.06$ & $0.83+/-0.09$ & $0.84+/-0.06$ & $0.87+/-0.09$ & $0.88+/-0.07$ \\
\hline Sensitivity & $0.73+/-0.06$ & $0.59+/-0.09$ & $0.62+/-0.08$ & $0.63+/-0.11$ & $0.64+/-0.03$ \\
\hline Kappa & $0.60+/-0.10$ & $0.42+/-0.14$ & $0.45+/-0.12$ & $0.47+/-0.14$ & $0.48+/-0.16$ \\
\hline
\end{tabular}


medRxiv preprint doi: https://doi.org/10.1101/2021.12.22.21268267; this version posted January 1, 2022. The copyright holder for this preprint (which was not certified by peer review) is the author/funder, who has granted medRxiv a license to display the preprint in perpetuity.

All rights reserved. No reuse allowed without permission.

Figure 1. Comparison between Laboratory PSG and At-Home Dreem Recording

Figure 1A. Total Sleep Time

Figure 1B. WASO
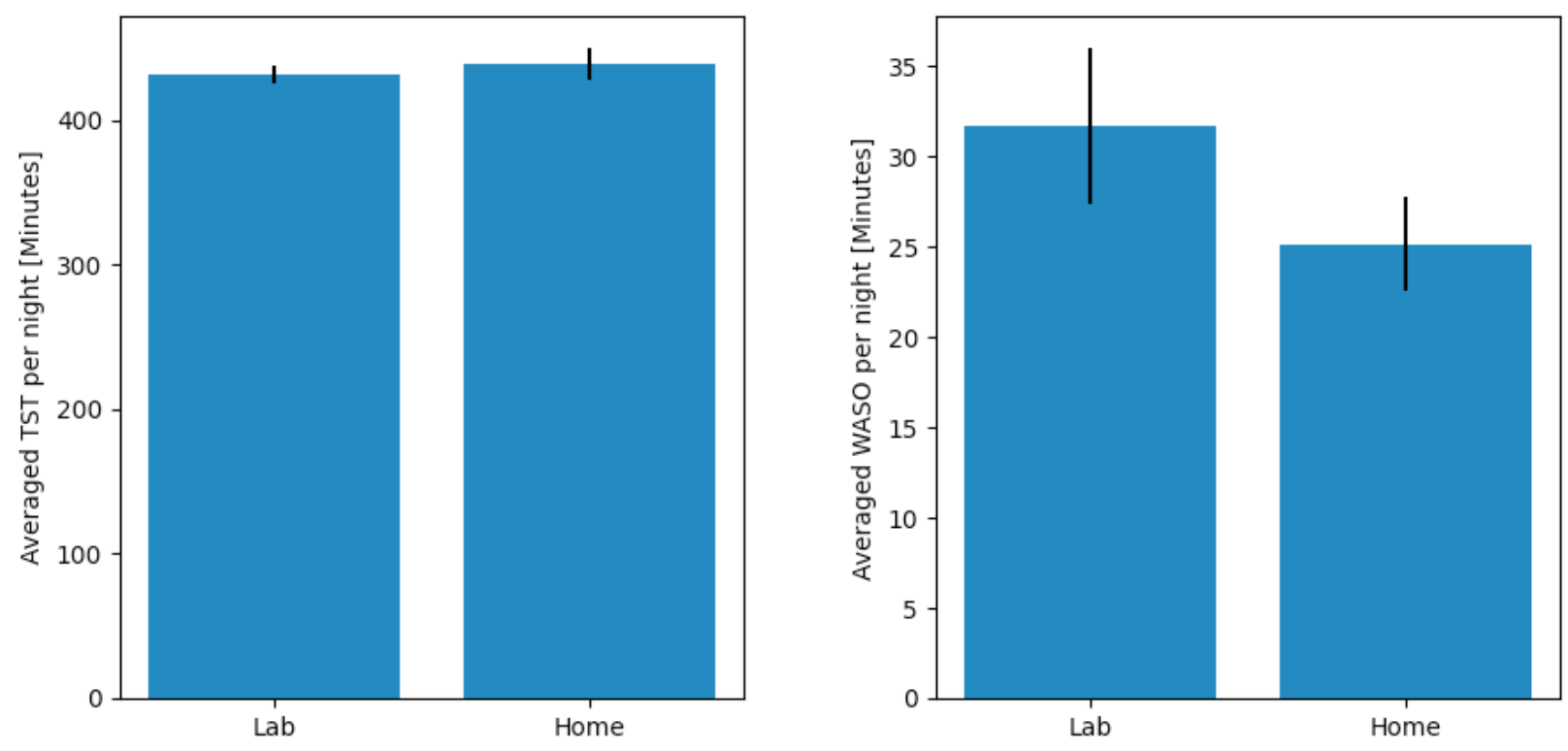

Figure 1C. Time in Each Sleep Stage
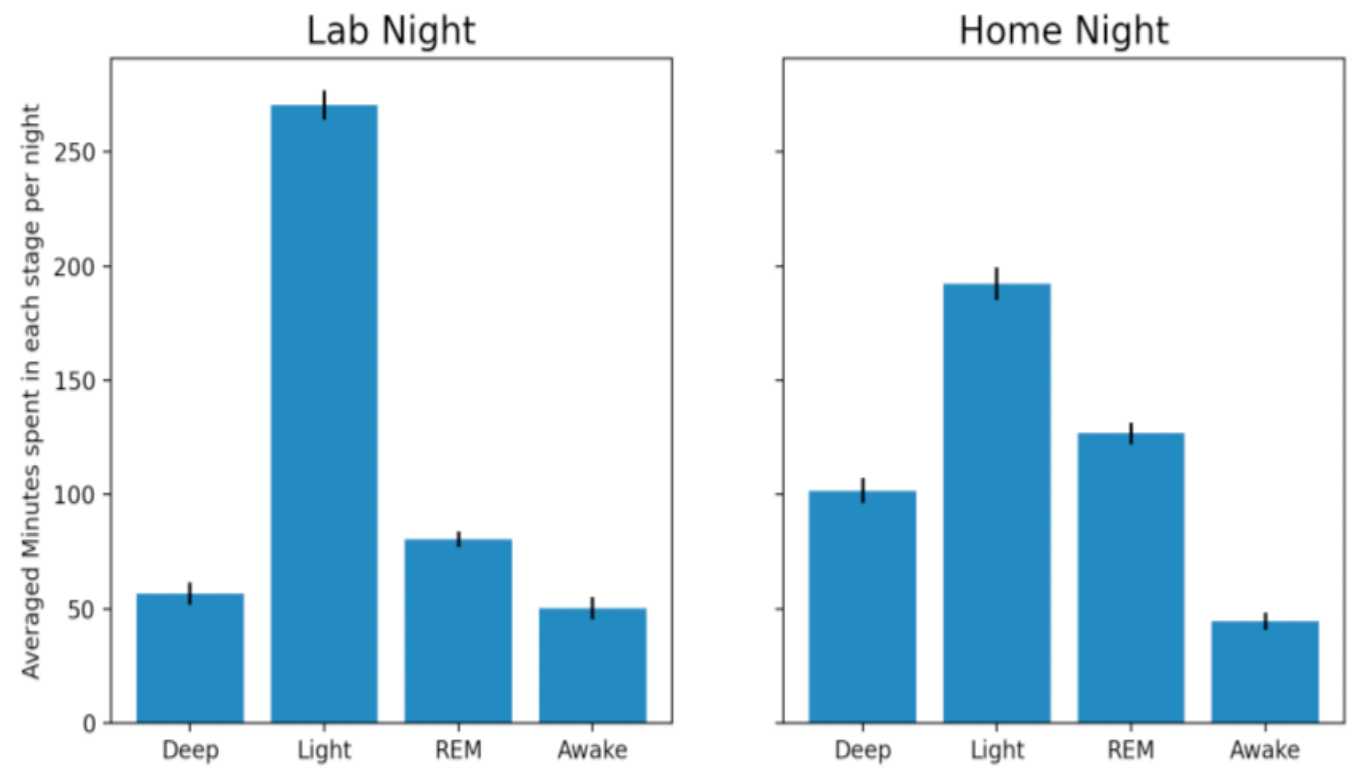
medRxiv preprint doi: https://doi.org/10.1101/2021.12.22.21268267; this version posted January 1, 2022. The copyright holder for this preprint (which was not certified by peer review) is the author/funder, who has granted medRxiv a license to display the preprint in perpetuity.

Figure 2. Comparison between Happy Algorithms and Both In-Lab and At-Home Polysomnography References

Figure 2A. Well-Performing Example in Lab
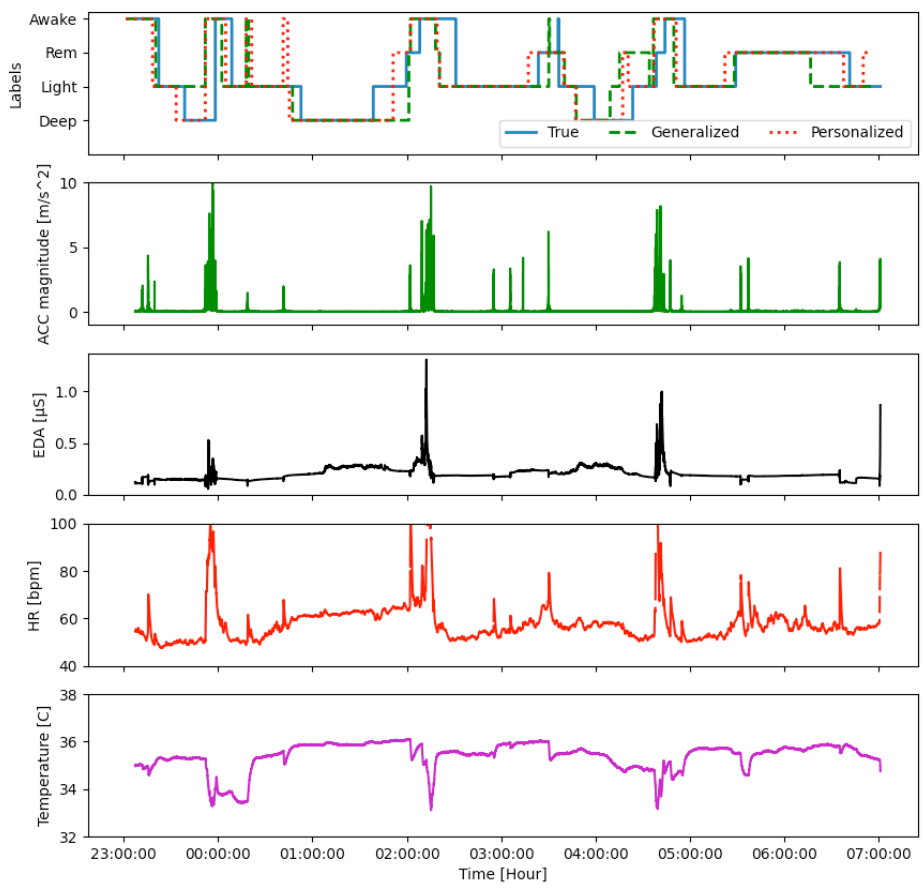

Figure 2B. Well-Performing Example At-Home
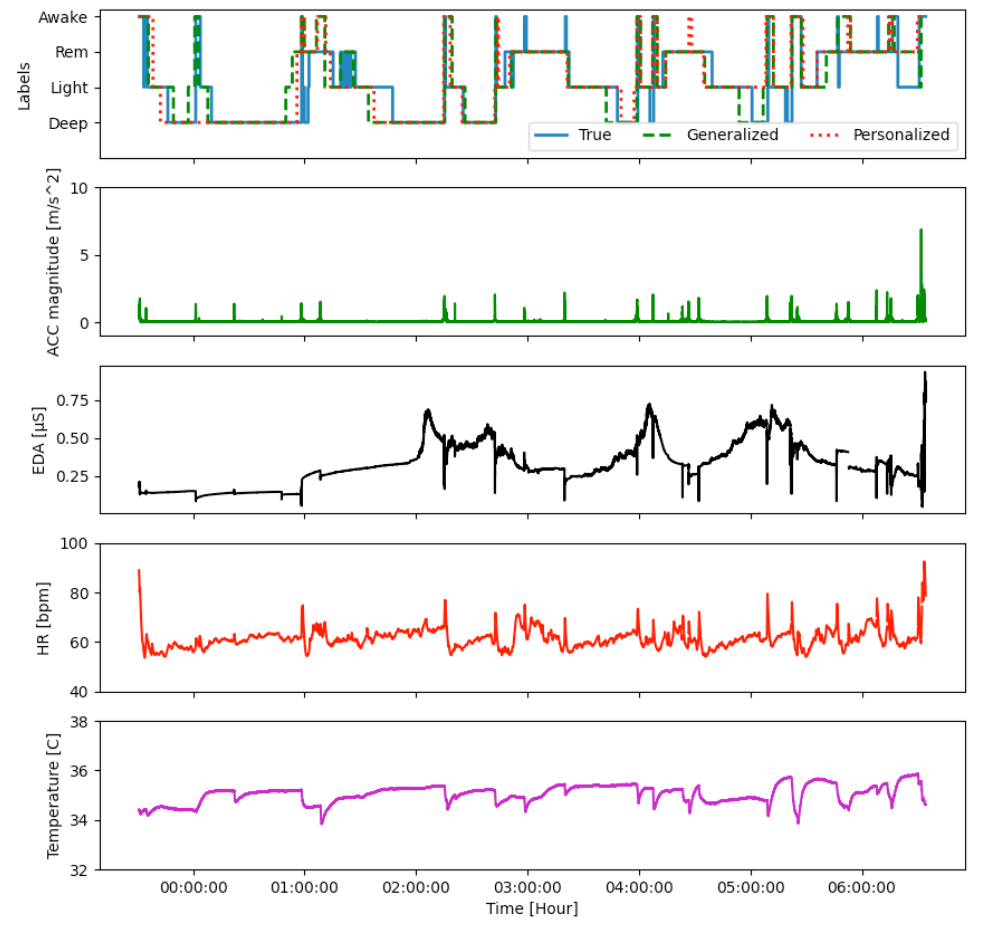
medRxiv preprint doi: https://doi.org/10.1101/2021.12.22.21268267; this version posted January 1, 2022. The copyright holder for this preprint (which was not certified by peer review) is the author/funder, who has granted medRxiv a license to display the preprint in perpetuity. All rights reserved. No reuse allowed without permission.

Figure 2C. Typical Performance Example In-Lab
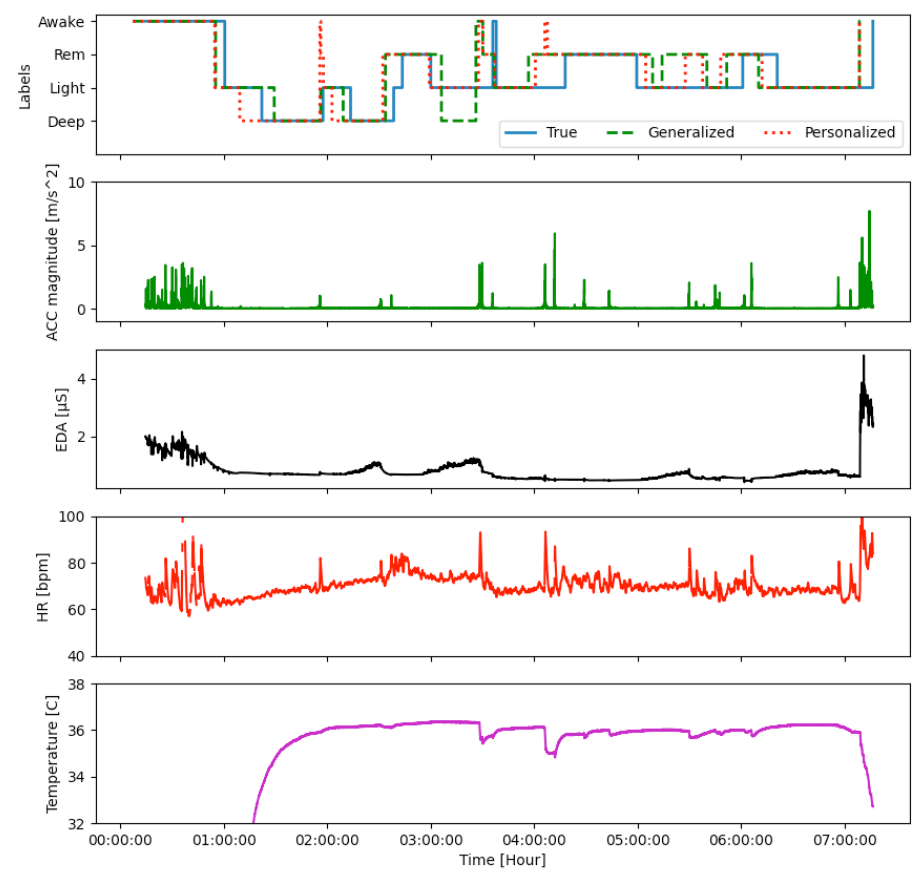

Figure 2D. Typical Performance Example At-Home
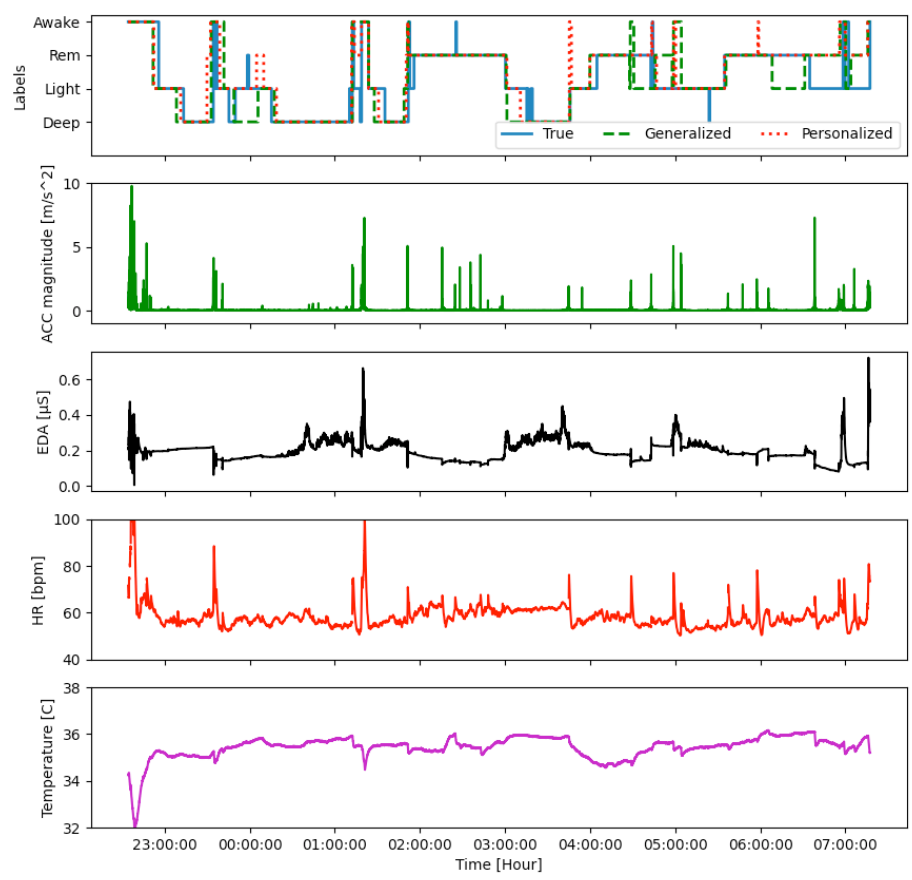
medRxiv preprint doi: https://doi.org/10.1101/2021.12.22.21268267; this version posted January 1, 2022. The copyright holder for this preprint (which was not certified by peer review) is the author/funder, who has granted medRxiv a license to display the preprint in perpetuity.

Figure 2E. Poorly-Performing Example In-Lab
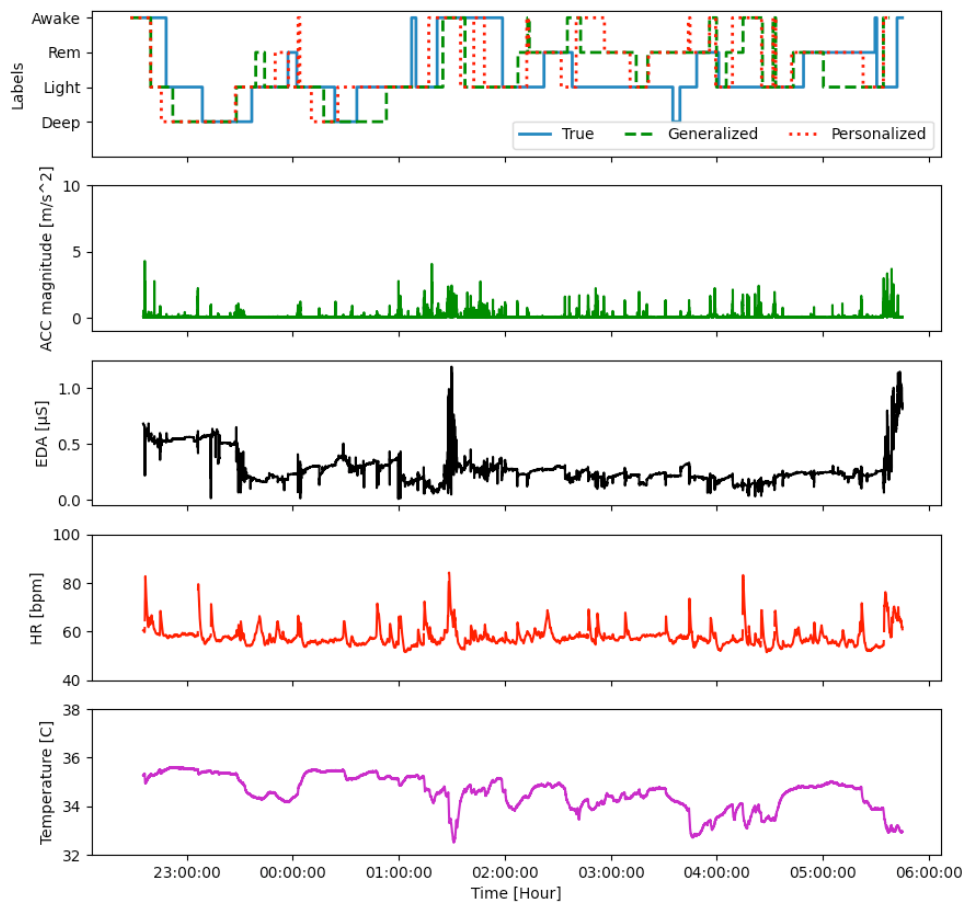

Figure 2F. Poorly-Performing Example At-Home
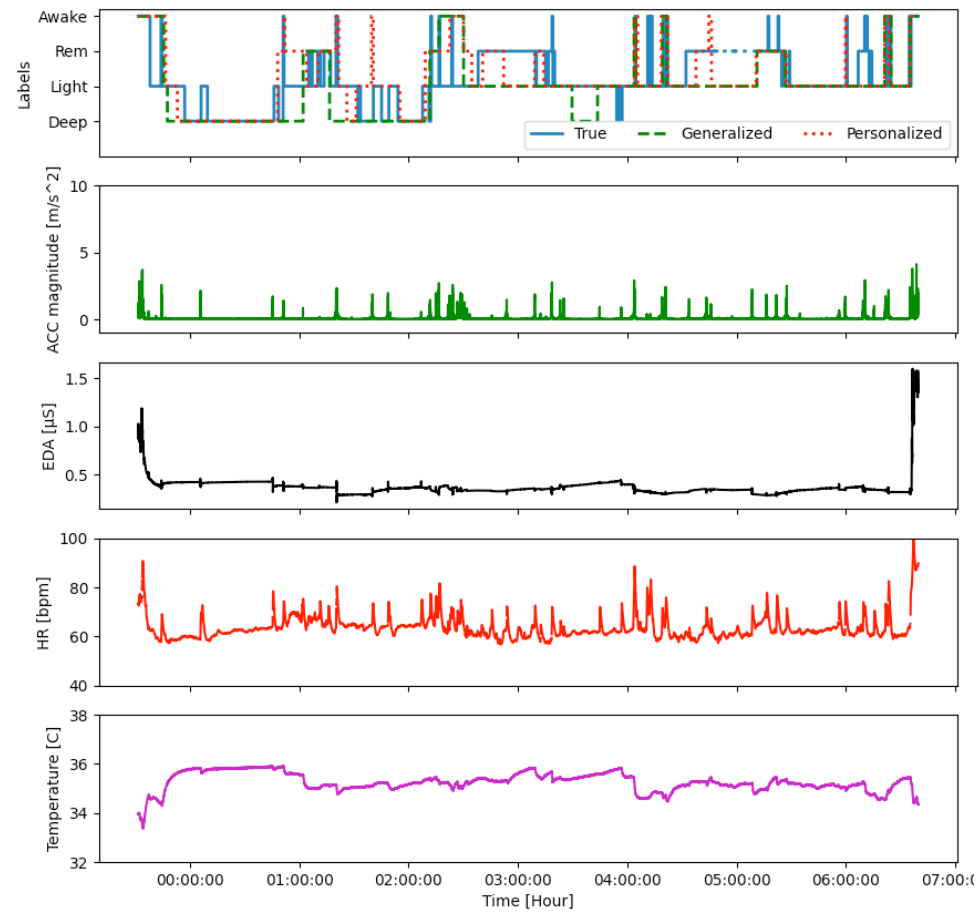
medRxiv preprint doi: https://doi.org/10.1101/2021.12.22.21268267; this version posted January 1, 2022. The copyright holder for this preprint (which was not certified by peer review) is the author/funder, who has granted medRxiv a license to display the preprint in perpetuity.

All rights reserved. No reuse allowed without permission.

Figure 3. Comparison of Deviations from In-Lab and At-Home Polysomnography for Happy Algorithms and Other Studied Devices

Figure 3A. In-Lab Total Sleep Time

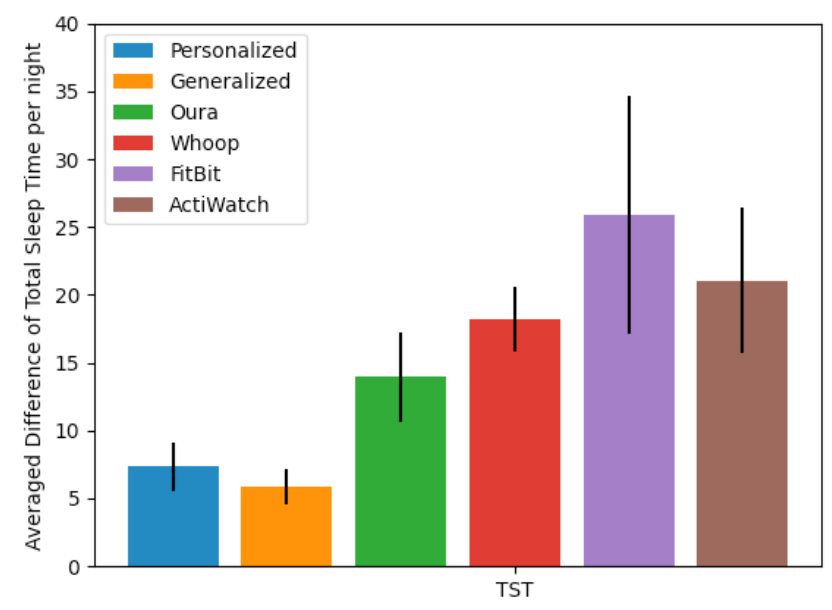

Figure 3B. In-Lab WASO

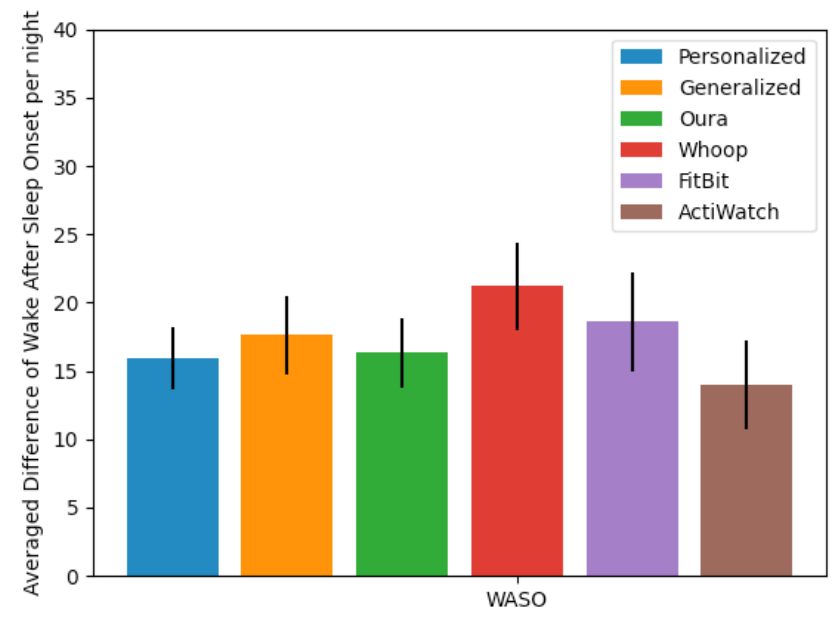

Figure 3C. In-Lab Time in Each Sleep Stage

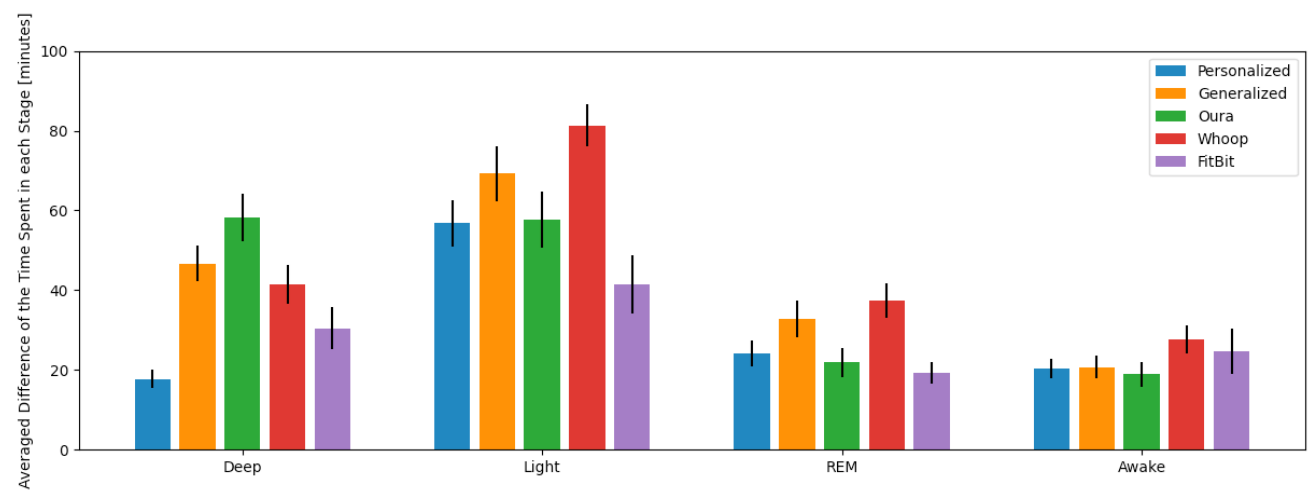


medRxiv preprint doi: https://doi.org/10.1101/2021.12.22.21268267; this version posted January 1, 2022. The copyright holder for this preprint (which was not certified by peer review) is the author/funder, who has granted medRxiv a license to display the preprint in perpetuity.

All rights reserved. No reuse allowed without permission.

Figure 3D. At-Home Total Sleep Time

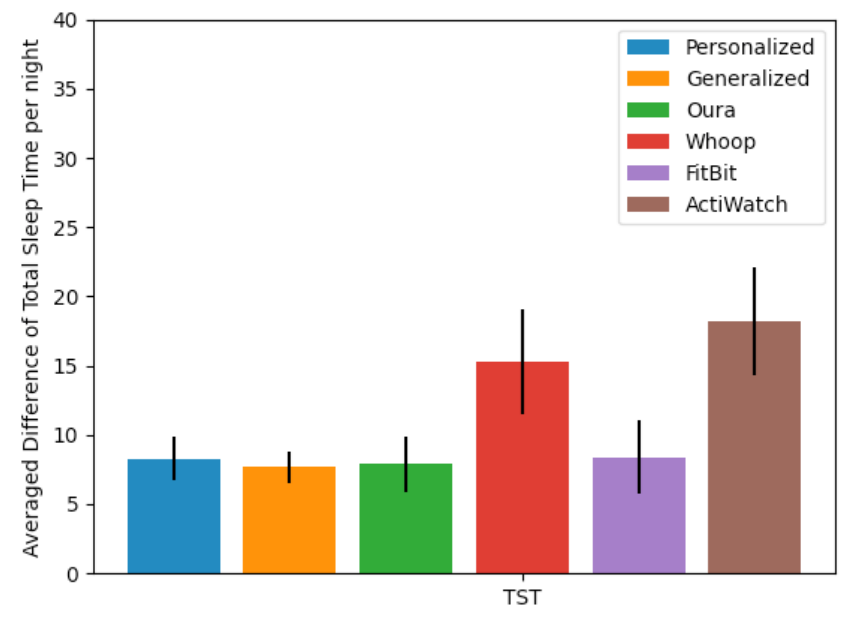

Figure 3E. At-Home WASO

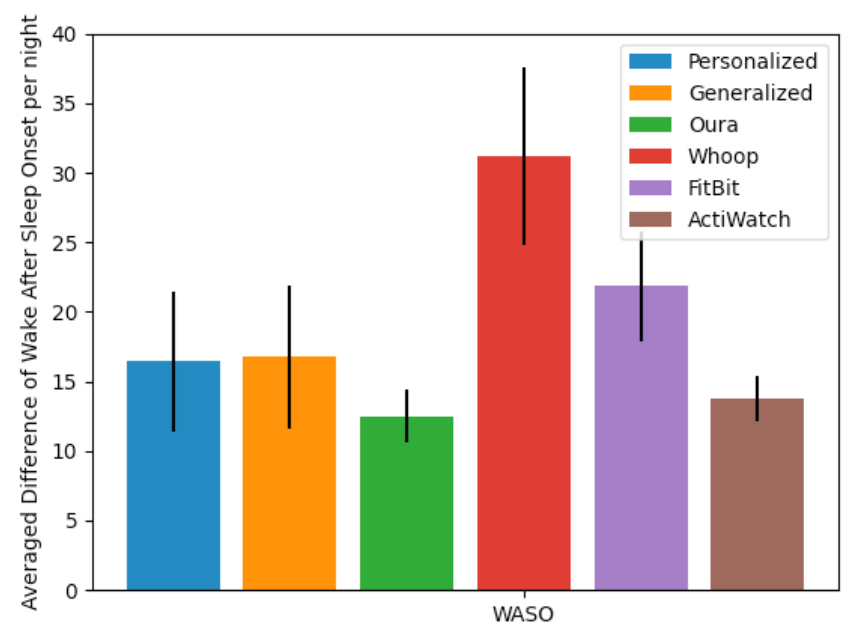

Figure 3F. At-Home Time in Each Sleep Stage

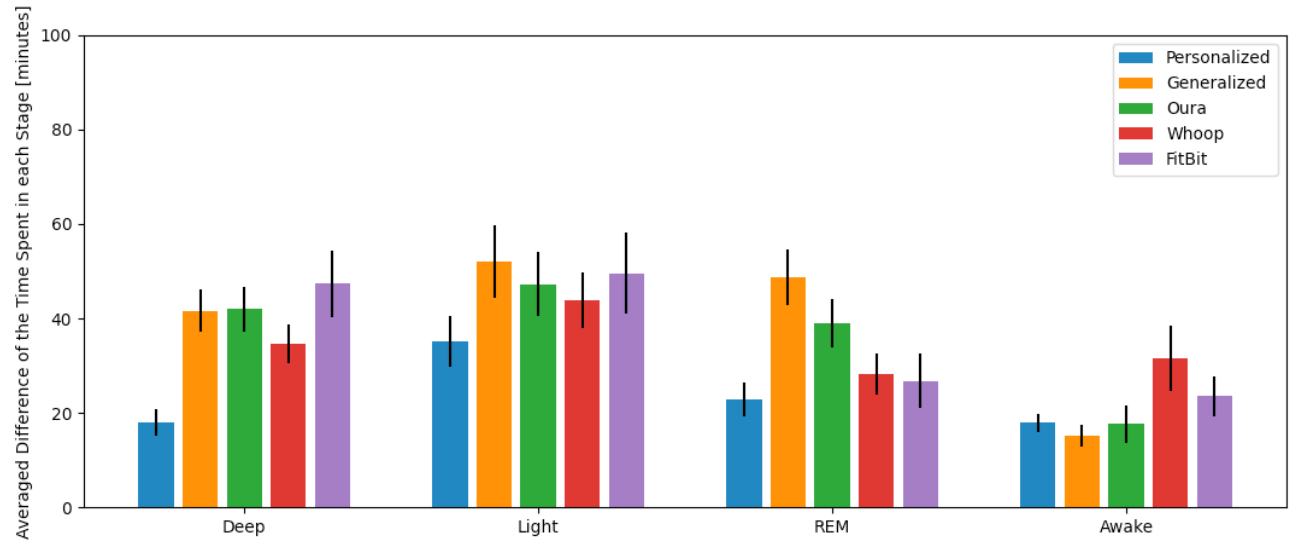


medRxiv preprint doi: https://doi.org/10.1101/2021.12.22.21268267; this version posted January 1, 2022. The copyright holder for this preprint (which was not certified by peer review) is the author/funder, who has granted medRxiv a license to display the preprint in perpetuity.

All rights reserved. No reuse allowed without permission.

Figure 4. Confusion Matrices Comparing Happy Algorithms to In-Lab and At-Home Polysomnography References

\section{A. Confusion Matrix for Happy Generalized In-Lab}

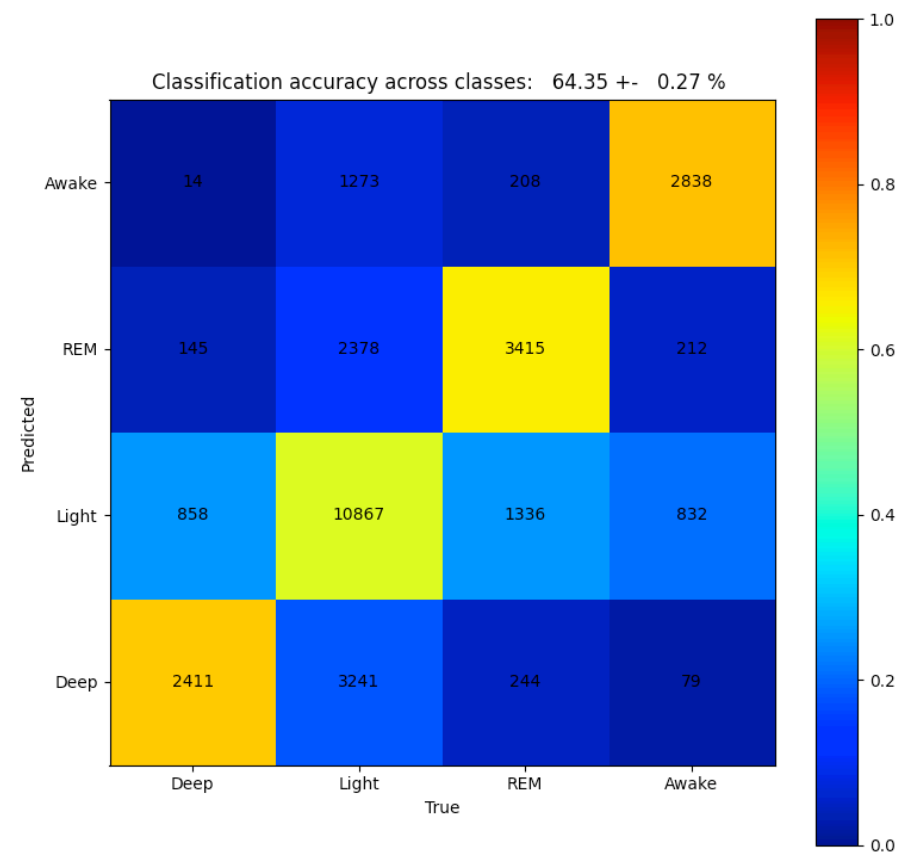

4B. Confusion Matrix for Happy Personalized In-Lab

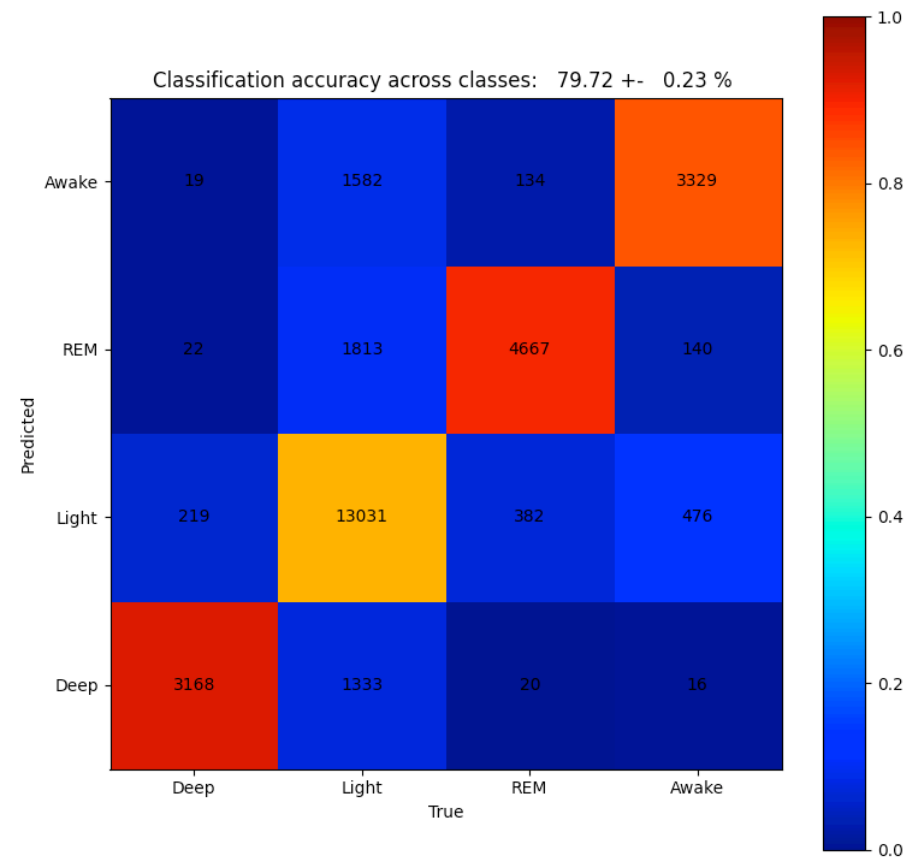


medRxiv preprint doi: https://doi.org/10.1101/2021.12.22.21268267; this version posted January 1, 2022. The copyright holder for this preprint (which was not certified by peer review) is the author/funder, who has granted medRxiv a license to display the preprint in perpetuity.

All rights reserved. No reuse allowed without permission.

\section{C. Confusion Matrix for Happy Generalized At-Home}

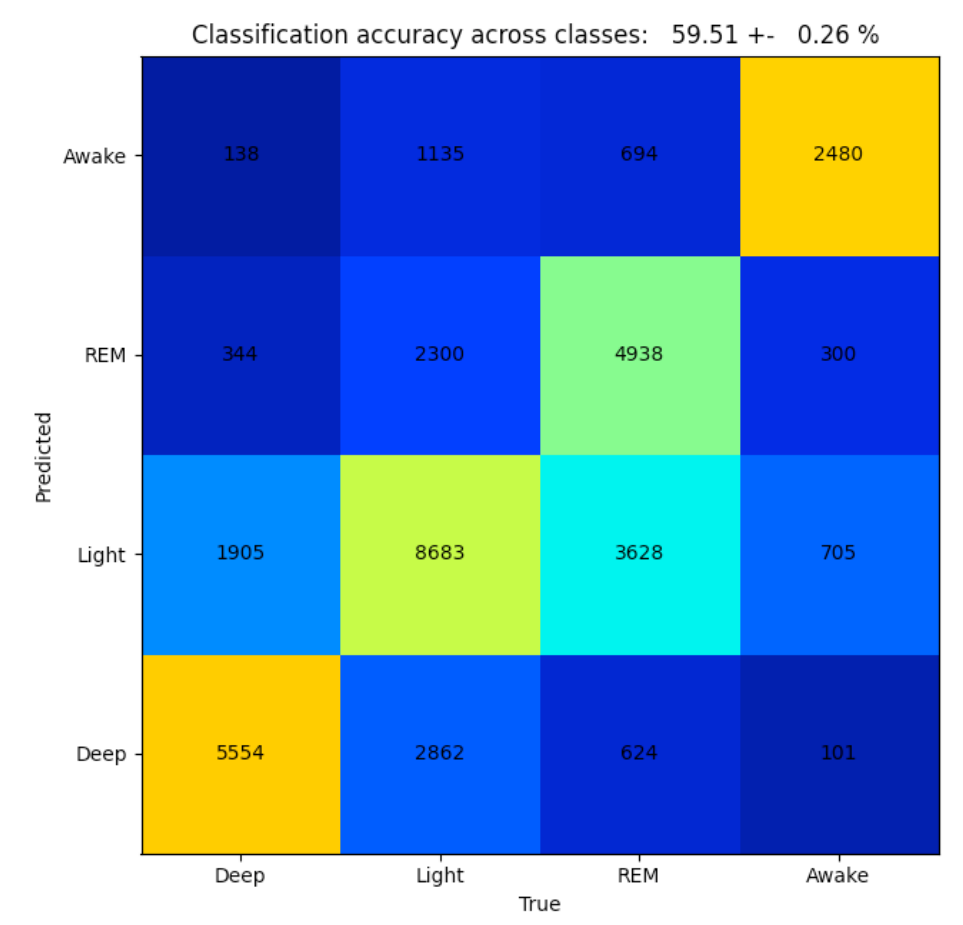

\section{D. Confusion Matrix for Happy Personalized At-Home}

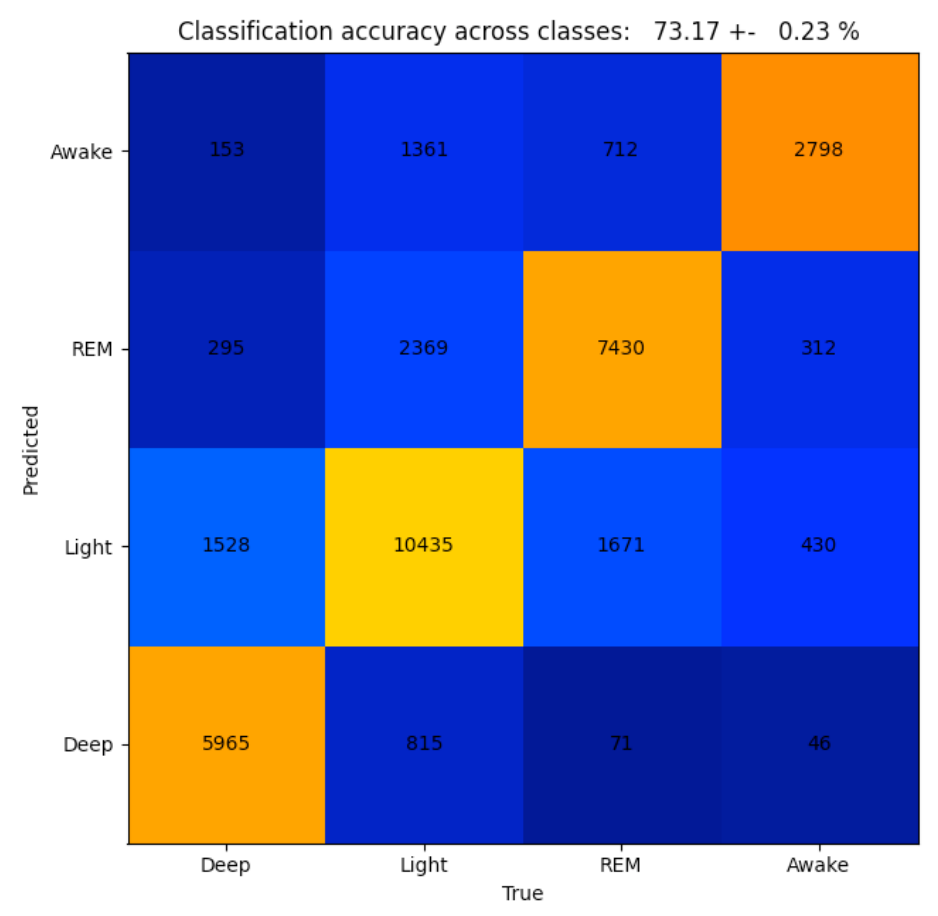


medRxiv preprint doi: https://doi.org/10.1101/2021.12.22.21268267; this version posted January 1, 2022. The copyright holder for this preprint (which was not certified by peer review) is the author/funder, who has granted medRxiv a license to display the preprint in perpetuity.

\section{Supplementary Materials}

Figure S1. Bland-Altman Plots Comparing Happy Generalized to In-Laboratory Polysomnography
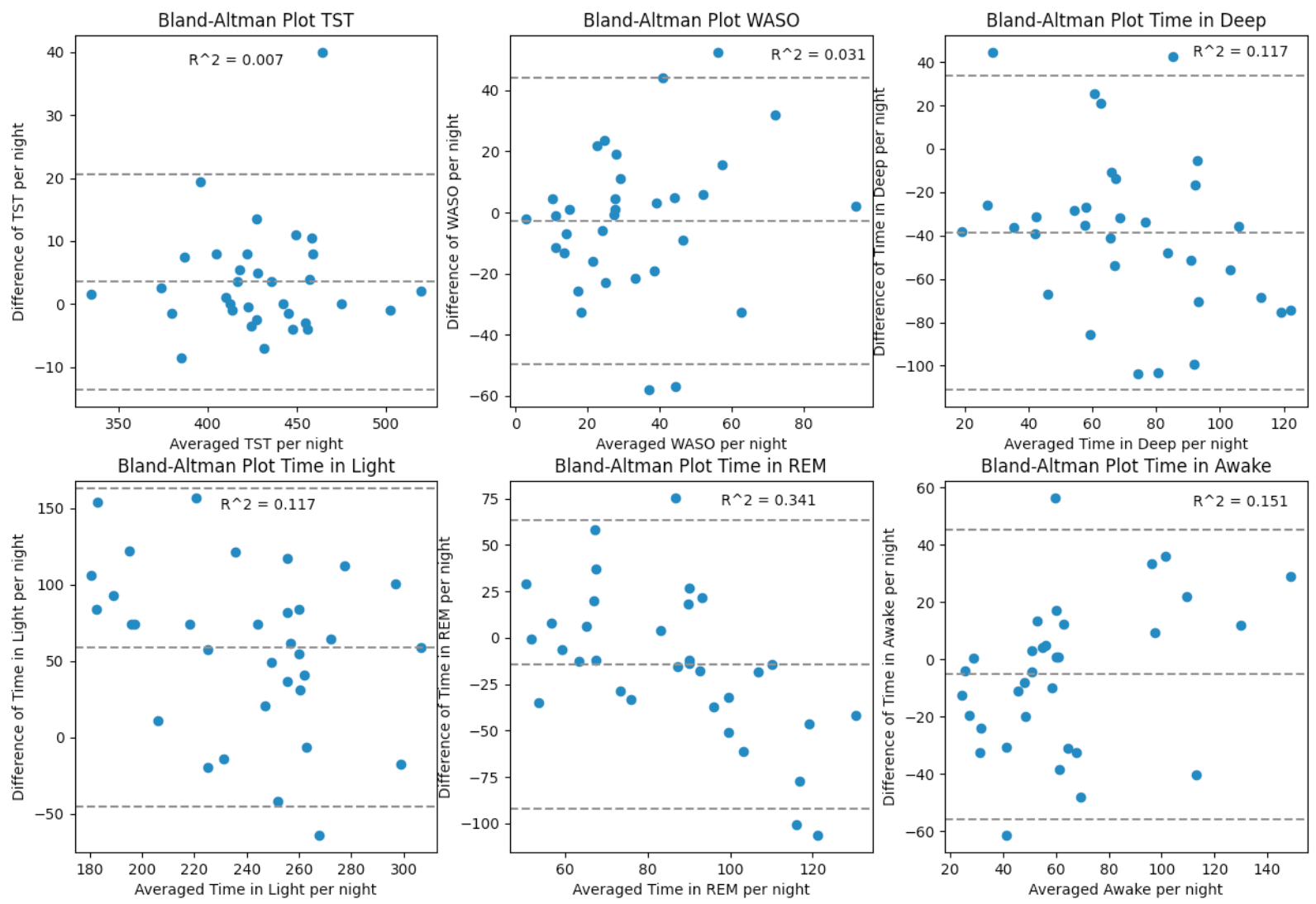
medRxiv preprint doi: https://doi.org/10.1101/2021.12.22.21268267; this version posted January 1, 2022. The copyright holder for this preprint (which was not certified by peer review) is the author/funder, who has granted medRxiv a license to display the preprint in perpetuity.

Figure S2. Bland-Altman Plots Comparing Happy Personalized to In-Laboratory Polysomnography
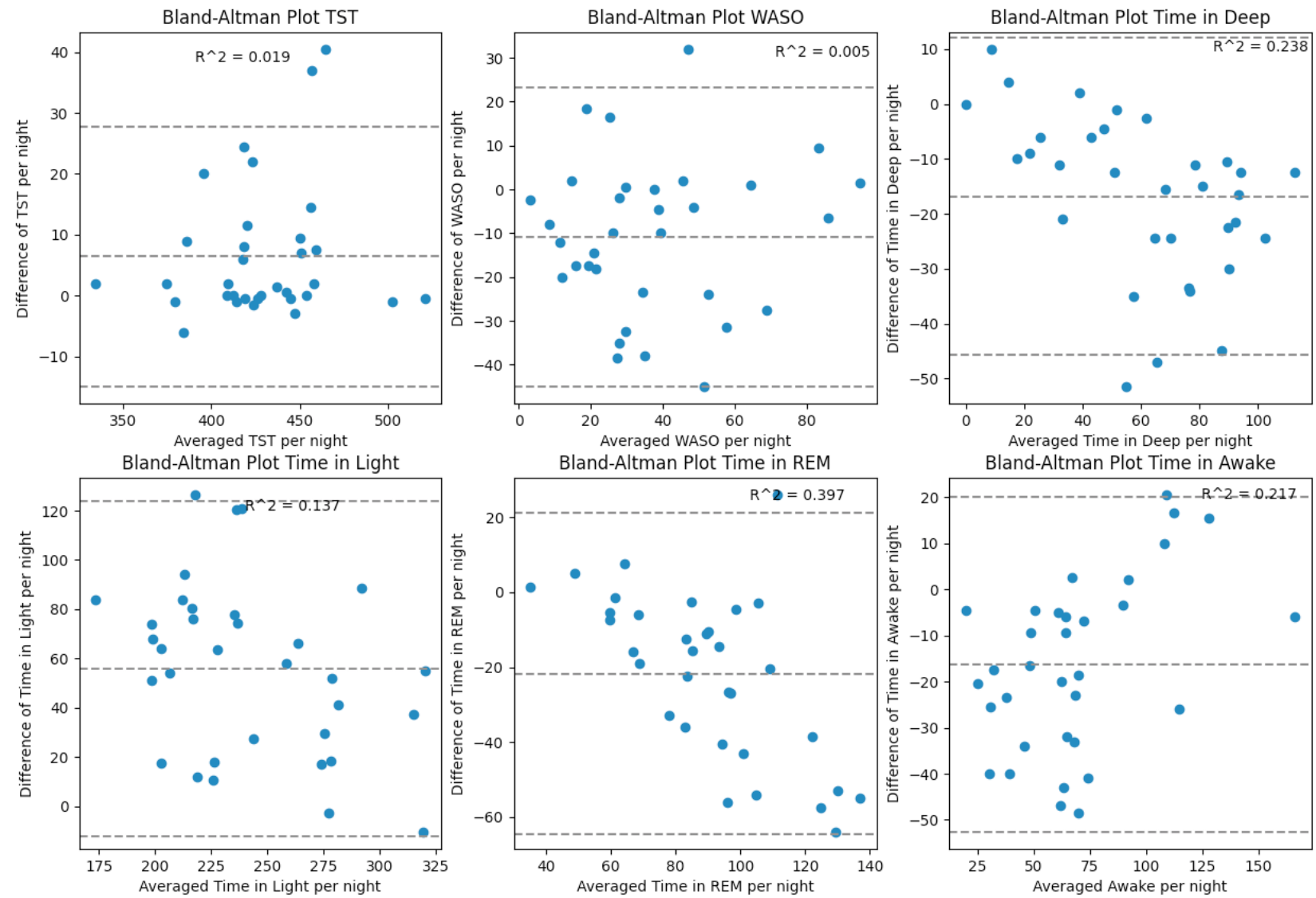
medRxiv preprint doi: https://doi.org/10.1101/2021.12.22.21268267; this version posted January 1, 2022. The copyright holder for this preprint (which was not certified by peer review) is the author/funder, who has granted medRxiv a license to display the preprint in perpetuity.

Figure S3. Bland-Altman Plots Comparing Happy Generalized to Home Polysomnography
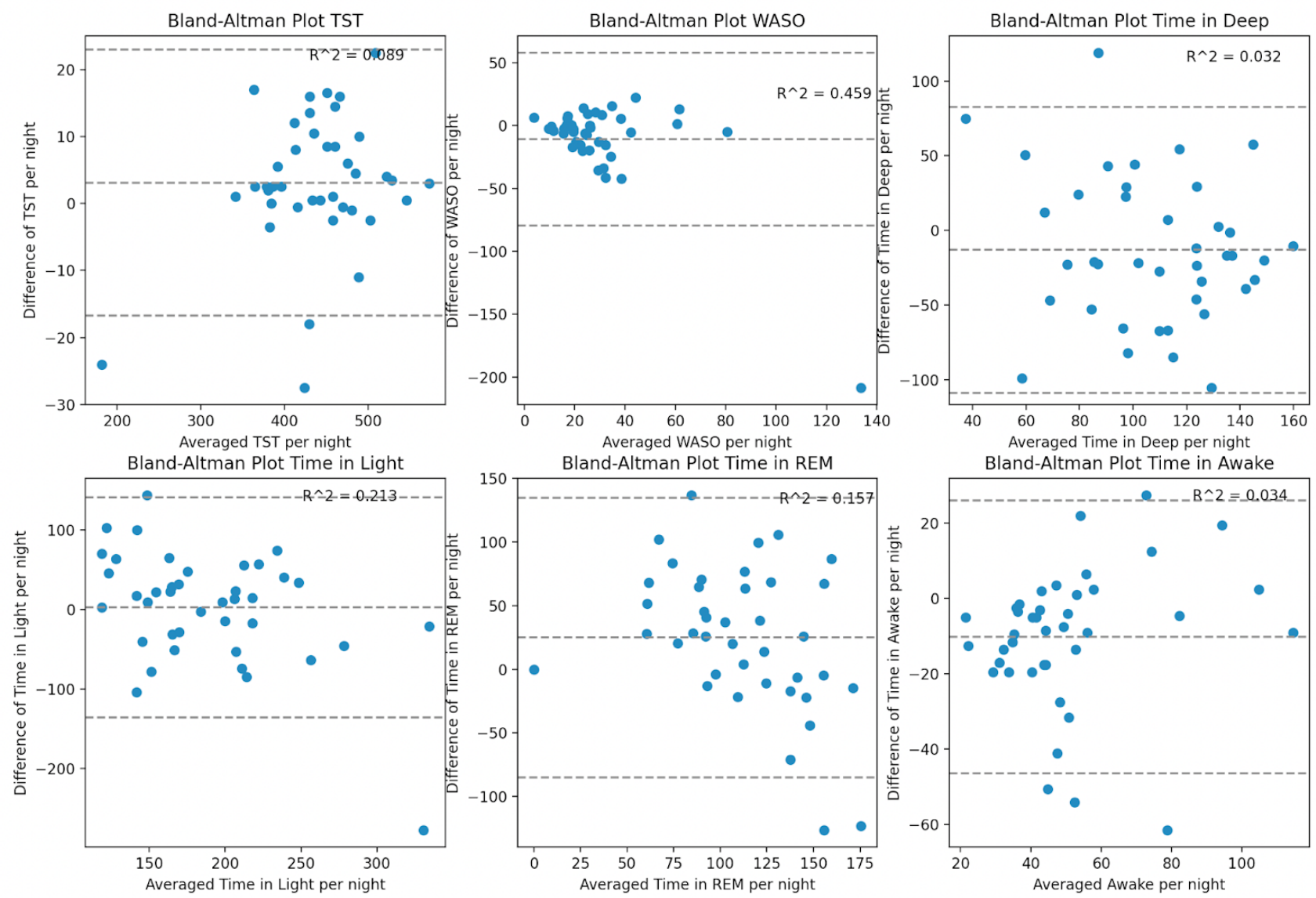
medRxiv preprint doi: https://doi.org/10.1101/2021.12.22.21268267; this version posted January 1, 2022. The copyright holder for this preprint (which was not certified by peer review) is the author/funder, who has granted medRxiv a license to display the preprint in perpetuity.

All rights reserved. No reuse allowed without permission.

\section{Figure S4. Bland-Altman Plots Comparing Happy Personalized to Home Polysomnography}
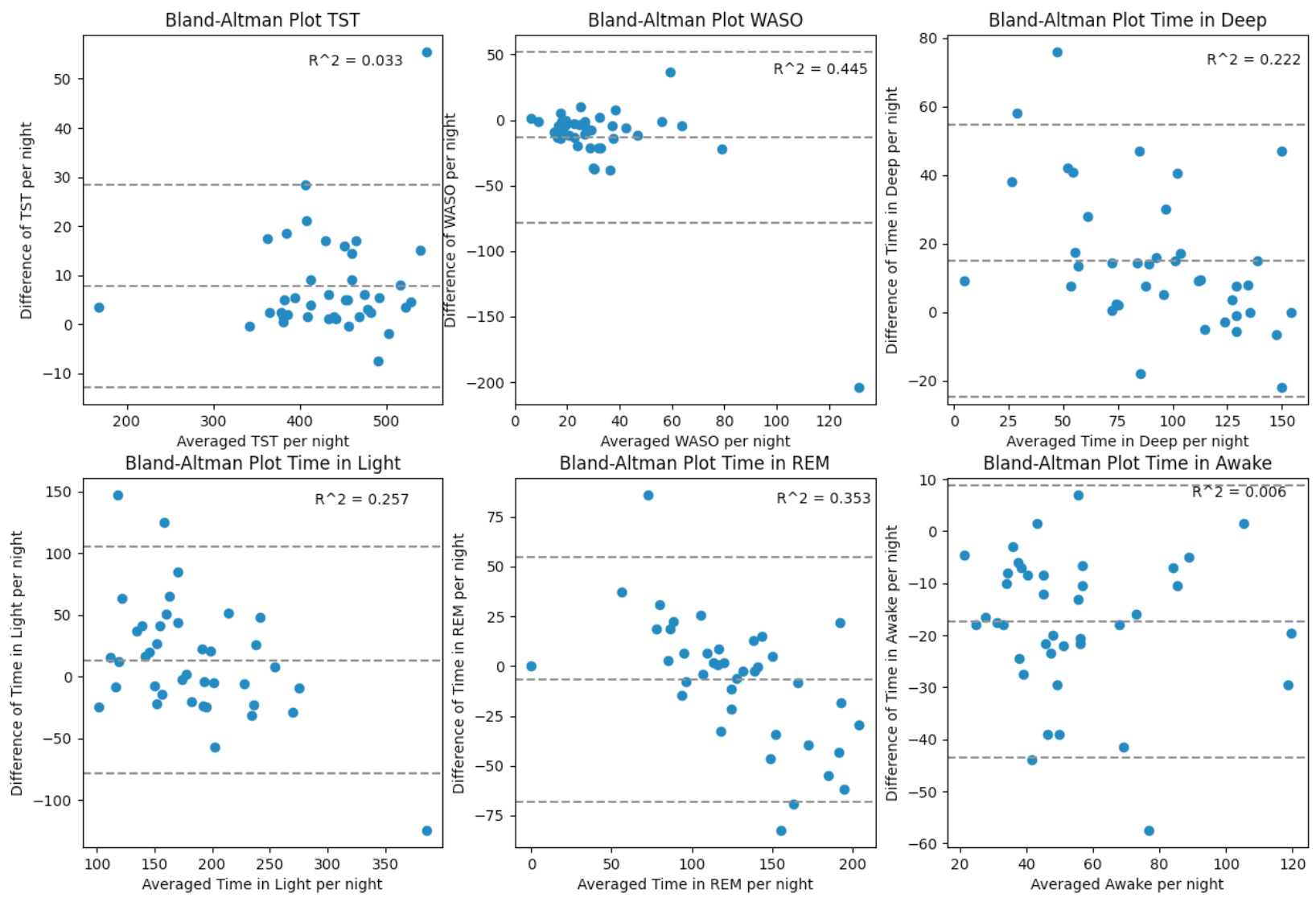